Document downloaded from:

http://hdl.handle.net/10251/141642

This paper must be cited as:

Robles Martínez, A.; Aguado García, D.; Barat, R.; Borrás Falomir, L.; Bouzas Blanco, A.; Bautista-Giménez, J.; Martí Ortega, N.... (03-2). New frontiers from removal to recycling of nitrogen and phosphorus from wastewater in the Circular Economy. Bioresource Technology. 300:1-18. https://doi.org/10.1016/j.biortech.2019.122673

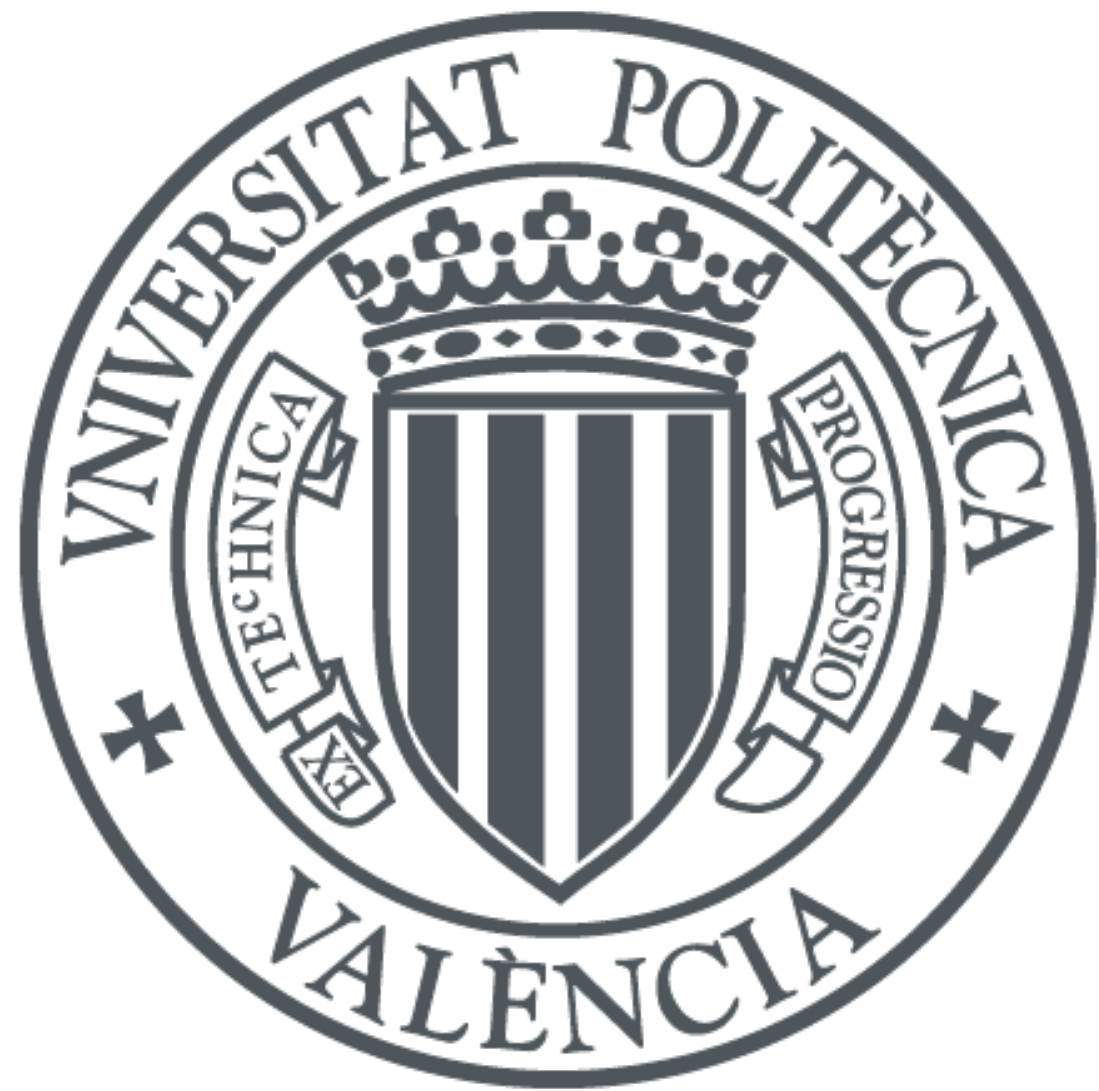

The final publication is available at

https://doi.org/10.1016/j.biortech.2019.122673

Copyright Elsevier

Additional Information 


\title{
New frontiers from removal to recycling of nitrogen and phosphorus from wastewater in the circular economy
}

Ángel Robles ${ }^{a}$, Daniel Aguado ${ }^{b}$, Ramón Barat ${ }^{b}$, Luis Borrás ${ }^{a}$, Alberto Bouzas a , Juan Bautista Giménez ${ }^{a}$, Nuria Martí a, Josep Ribes a, Maria Victoria Ruano ${ }^{a}$, Joaquín Serralta ${ }^{b}$, José Ferrer ${ }^{b}$, Aurora Seco a

aCALAGUA - Unidad Mixta UV-UPV, Departament d'Enginyeria Química, Universitat de València, Avinguda de la Universitat s/n, 46100, Burjassot, València, Spain

'CALAGUA - Unidad Mixta UV-UPV, Institut Universitari d'Investigació d'Enginyeria de l'Aigua i Medi Ambient IIAMA, Universitat Politècnica de València, Camí de Vera s/n, 46022, València, Spain.

\begin{abstract}
Nutrient recovery technologies are rapidly expanding due to the need for the appropriate recycling of key elements from waste resources in order to move towards a truly sustainable modern society based on the Circular Economy. Nutrient recycling is a promising strategy for reducing the depletion of non-renewable resources and the environmental impact linked to their extraction and manufacture. However, nutrient recovery technologies are not yet fully mature, as further research is needed to optimize process efficiency and enhance their commercial applicability. This paper reviews state-of-the-art of nutrient recovery, focusing on frontier technological advances and economic and environmental innovation perspectives. The potentials and limitations of different technologies are discussed, covering systems based on membranes, photosynthesis, crystallization and other physical and biological nutrient recovery systems (e.g. incineration, composting, stripping and absorption and enhanced biological phosphorus recovery).
\end{abstract}

\section{Keywords}

Circular Economy, Crystallization; Membranes; Nutrient recovery; Photosynthetic-based systems

\section{Contents}

1. INTRODUCTION 2

1.1. CirCular ECONOMY IN WASte tREATMENT 2

1.2. THE ROLE OF INORGANIC NUTRIENTS IN THE CIRCULAR ECONOMY

2. MEMBRANE-BASED SYSTEMS FOR NUTRIENT RECOVERY

2.1. MeMBRANe-BASED TECHNOLOGIES

2.1.1. FORWARD OSMOSIS 5

2.1.2. MEMBRANE CONTACTORS 6

2.1.3. ELECTRODIALYSIS

2.1.4. BIOELECTROCHEMICAL SYSTEMS

2.1.5. ANMBR 8

2.1.6. DIRECT FILTRATION 9 
2.2. Potentials AND Limitations 10

3. PHOTOSYNTHETIC-BASED SYSTEMS FOR NUTRIENT RECOVERY 12

3.1. PHOTOSYNTHETIC-BASED TECHNOLOGIES

3.1.1. MicROALGAE-BASED TECHNOLOGY 13

3.1.2. PHOTOSYNTHETIC-BACTERIA-BASED TECHNOLOGY 16

3.2. POTENTIALS AND LIMITATIONS 17

4. RYSTALLIZATION-BASED SYSTEMS FOR NUTRIENT RECOVERY 18

4.1. CRYstallization-Based teCHNOlogies 18

4.1.1. STRUVITE

4.1.2. VIVIANITE 19

4.1.3. OTHER PRECIPITATES 20

4.2. POTENTIALS AND LIMITATIONS 21

5. OTHER SYSTEMS FOR NUTRIENT RECOVERY

5.1. OTHER PHYSICAL AND BIOLOGICAL TECHNOLOGIES

5.1.1. INCINERATION 23

5.1.2. SLUDGE COMPOSTING AND DIRECT LAND APPLICATION 24

5.1.3. AMMONIA STRIPPING AND ABSORPTION 25

5.1.4. EMERGING ENHANCED NUTRIENT RECOVERY 26

5.1.4.1. CONVERSION OF NON-REACTIVE P INTO REACTIVE P 26

5.1.4.2. INNOVATIVE P RECOVERY PROCESSES COMBINED WITH GRANULAR SLUDGE SYSTEMS 27

5.1.4.3. INNOVATIVE P RECOVERY PROCESSES ASSOCIATED WITH SULFUR CYCLE 27

5.1.4.4. NUTRIENT RECOVERY VIA ADSORPTION AND ION EXCHANGE 28

5.2. POTENTIALS AND LIMITATIONS 29

6. GeNERAL REMARKS AND FUtURE PERSPECTIVES 30

7. CONCLUSIONS 33

\section{Introduction}

\subsection{Circular Economy in waste treatment}

The Earth has gone through different geological eras in its history, during which extreme climatic conditions have alternated with periods of climate stability. For the last 10,000 years, or Holocene Period, the environment has remained unusually stable and environmental change has been autoregulated by means of different interconnected natural systems. Nonetheless, the industrial revolution was the starting point of the Anthropocene Period, a new era in which the climate changes are derived from human activities (Rockström et al., 2009). 
The post-industrial economic model has remained unchanged since its very beginning, and has followed a linear consumption pattern that overlooks the finite nature of raw materials. So far, innovation has been used as a means of creating economic value rather than reducing the human impact on the biosphere, so that the focus has been on optimizing existing systems rather than steering innovation towards sustainability (Westley et al., 2011). Indeed, as a result of the marked dependence of industrial economies on fossil fuels and intensive farming, which produce massive flows of wastes, the natural regulatory capacity of the Earth's systems is currently being exceeded and threatens the Holocene's prevailing environmental stability (Rockström et al., 2009).

In accordance with the prevailing linear economic model, current production and consumption practices only consider treating waste streams when they involve a potential risk to the environment, whilst recovering valuable resources is only considered when it entails an economic benefit to the production process. However, many companies are already noting increased exposure to steadily rising and less predictable resource prices as a result of the expanding population and urban agglomeration, and the depletion of easily reachable resources, which increases the environmental cost associated with exploitation (MacArthur, 2013). Working towards optimizing goods production alone, in terms of reducing the specific demand for raw materials and energy, will only postpone the eventual depletion of resources. Acknowledging the finite nature of the stocks and the detrimental effect of their discharge into the environment is giving rise to an increasingly concerned society that recognizes the urgent need for innovation systems focusing on biosphere-conservation that will lead to sustainable production and consumption habits by minimizing resource wastage. In this respect, the adoption of a Circular Economy (CE) is required, entailing a demand-based stock control, the minimum use of resources and recycling used goods into the production cycle.

The term CE denotes an economic model aimed at restoring the environment. CE attempts to maximize benefits whilst relying on renewable energy, eliminating the use of toxic chemicals and focusing product design on waste reduction. Products are conceived as an assembly of components that serve for a specific purpose during their lifetime, after which they are dismantled and the components are used in 
new products (MacArthur, 2013). This approach has already been proved effective in several industries, where the reintroduction of used components has significantly offset the requirements for raw materials (Dobbs et al., 2011). CE techniques applied to waste treatment involve not only the removal of contaminants to prevent environmental damage, but also recover them as valuable products to be re-used in other production cycles.

\subsection{The role of inorganic nutrients in the Circular Economy}

Rockström et al. (2009) reported a framework based on the definition of 'planetary boundaries', which define 'the safe operating space for humanity with respect to the Earth system', that anthropogenic reactive forms of nitrogen $(\mathrm{N})$ and phosphorus $(\mathrm{P})$ are large enough to destabilize their natural fate. Intensive farming is considered as the major contributor to $\mathrm{N}$ - and $\mathrm{P}$-induced environmental change as a result of the massive use of fertilizers and the $\mathrm{N}$-fixation capacity of leguminous crops. According to these authors, the combined effect of all terrestrial processes converting atmospheric $\mathrm{N}_{2}$ into reactive $\mathrm{N}$-forms yields around 35 million tons per year, which account for one fourth of the atmospheric $\mathrm{N}_{2}$ converted by human processes. Unlike N, $\mathrm{P}$ is obtained from phosphate rock-mining. Around 20 million tons of $\mathrm{P}$ are mined every year and it is used in a wide range of applications. Most of the human-converted reactive $\mathrm{N}$ and mined $\mathrm{P}$ end-up in the environment, eroding the resilience of important Earth subsystems $\left(\mathrm{N}_{2} \mathrm{O}\right.$ as greenhouse gas increases radiative forcing, turbidity and anoxia in water bodies with distorted N- and Pcycles), while advancing towards depletion (not the case with N, but the energy-intensive Haber-Bosch process used to activate $\mathrm{N}$ mostly depends on fossil fuels). Indeed, $\mathrm{P}$ was included in the Critical Raw Materials list of the European Union in 2017 due to the supply risk and its economic importance. P deposits are unevenly distributed and even today fertilizer quality issues frequently arise (Günther et al., 2018). Other authors forecast that $P$ production will peak within this century (Cordell and White, 2013) as a result of the increased need for food production, so that a future P shortage could limit food production. This risk is especially important in Mediterranean countries with high levels of food production such as Spain and Italy, who provided around $33 \%$ and $51 \%$ of the European production of fruit and vegetables, respectively, in 2017. 
As a result of their several uses, most of the $\mathrm{N}$ and $\mathrm{P}$ used for human activities eventually find their wastewater-borne way to the oceans, increasing the risk of anoxia and eutrophication. Current wastewater treatment plants discharging to eutrophication sensitive areas remove $\mathrm{N}$ and $\mathrm{P}$ from their effluent, mostly by air stripping (nitrification/denitrification) and biological and/or chemical precipitation, respectively. However, the recovery of these nutrients from wastewaters would not only prevent this risk, but also encourage the transition towards a CE-based development model. In the CE pattern, wastewater treatment facilities are designed to fit a materials cycle in which waste does not exist and are rather conceived as water resource recovery facilities (WRRF). Nutrients should be properly recovered in order to be reintroduced into the biosphere to safely produce new natural capital.

The present review describes the state-of-the-art of current technologies devoted to $\mathrm{N}$ and $\mathrm{P}$ recovery from wastewater and the extent of the contribution of each technology to the transition towards a CEbased development model is discussed.

\section{Membrane-based systems for nutrient recovery}

\subsection{Membrane-based technologies}

Membrane systems can be considered as an effective and selective technology for nutrient recovery from wastewater. Forward osmosis (FO), hollow-fiber membrane contactors (HFMC), electrodialysis (ED) or bioelectrochemical system (BES) are highly selective on $\mathrm{N}$ and/or $\mathrm{P}$ and can replenish resources for biofertilizer production, overcoming negative environmental impacts of wastewater treatment (Yan et al., 2018). For instance, $\mathrm{N}$ can be recovered as ammonium sulfate by using sulfuric acid solution by HFMC, while P can be fractioned as phosphoric acid by ED (Xie et al., 2016). Anaerobic membrane bioreactors (AnMBR) and direct membrane filtration (DMF) can be applied as a previous step for fertigation or other nutrient recovery system. The different membrane-based treatment schemes thus have the potential to overcome the challenges of nutrient recovery from wastewater and potentially represent a paradigm shift in wastewater nutrient management (Xie et al., 2016). Figure 1 shows some examples of membrane hybrid systems for $\mathrm{N}$ and $\mathrm{P}$ recovery from wastewater.

\subsubsection{Forward osmosis}


FO is regarded as a potential low-energy solution for nutrient recovery (Lutchmiah et al., 2014). In this technology, the driving force for the transport of water molecules through the membrane is the naturally occurring osmotic pressure. The advantages of FO for nutrient recovery include: rejection of salts, low energy input due to the low hydraulic pressure required, production of good quality water, and lower fouling propensities than other systems (Lutchmiah et al., 2014).

Different configurations have been tested for recovering nutrients and reclaimed water for sustainable agriculture and water recycling in arid regions, such as FO-reverse osmosis (RO) process configuration, osmotic dilution process, osmotic membrane bioreactor (OMBR), and fertilizer-drawn FO (FDFO) process (Awad et al., 2019). By way of example, Singh et al. (2019) achieved recoveries of phosphate $\left(\mathrm{PO}_{4}{ }^{3-}\right)$ and ammonia $\left(\mathrm{NH}_{3}, \mathrm{FAN}\right)$ of $75 \%$ and $66 \%$, respectively, using divalent magnesium chloride as the draw solution. Volpin et al. (2019) recovered $93 \%$ of the $\mathrm{P}$ and $50 \%$ of the $\mathrm{N}$ from dilute human urine. The economic analysis revealed that the revenue from the fertilizers produced could potentially offset the overall costs of the system. However, integrating pressure-assisted osmosis and FDFO could further enhance the economics of the process due to enhancing water fluxes (Kim et al., 2019).

\subsubsection{Membrane contactors}

HFMC are a promising technology for $\mathrm{N}$ recovery. In these systems, ammonia passes through a microporous hydrophobic membrane and a sulfuric acid solution is used as draw solution to recover $\mathrm{N}$ as a valuable product (e.g. ammonium sulfate). The difference between $\mathrm{NH}_{3}$ concentrations on both sides of the membrane is the driving force. The small pore size and the hydrophobic nature of the membrane prevent the liquid phase from entering into the pores due to surface tension (Darestani et al., 2017). Two different membrane configurations can be applied for $\mathrm{N}$ recovery: pumping $\mathrm{N}$-rich solution into the lumen side and acid solution into the shell side, or vice versa. Several authors have proved that a higher mass transfer coefficient is obtained when the feed solution is pumped into the lumen side (Agrahari et al., 2012). However, fouling should be avoided within this configuration by a pre-treatment based on microfiltration or ultrafiltration membranes. Other authors proposed pumping the feed solution into the shell side or using submerged membrane modules without any outer shell (Wäeger-Baumann and Fuchs, 
2012).

The diffusion rate of $\mathrm{NH}_{3}$ through the membrane depends on the $\mathrm{NH}_{3}$ concentration in the feed solution, which in turns depends on $\mathrm{pH}$ and temperature. The feed solution $\mathrm{pH}$ can be raised by adding alkali to assist the transformation of ammonium $\left(\mathrm{NH}_{4}+\right)$ into $\mathrm{NH}_{3}$, enabling it to go through the microporous hydrophobic membrane. pH can also be raised by aeration (Daguerre-Martini et al., 2018), which reduces the cost.

HFMCs have been successfully applied for the recovery of $\mathrm{N}$ from different streams, such as reject water from sludge dewatering systems (Seco et al., 2018) or animal manure (Fillingham et al., 2017), among others. To our knowledge, the first application of full-scale HFMCs was recently reported by Richter et al. (2019).

\subsubsection{Electrodialysis}

ED is a well-known process that has been applied for more than 50 years on a large industrial scale for drinkable water production from brackish water sources and has recently been combined with bipolar membranes or with ion-exchange resins for different purposes, such as nutrient recovery from wastewater (Zhang et al., 2013). ED processes use an alternating series of cation and anion exchange membranes between the terminal anode and cathode. The applied current generates an internal electrical potential gradient that is used to concentrate or dilute ions from an aqueous solution through ion migration. ED has been applied for $\mathrm{N}$ and/or $\mathrm{P}$ recovery from different streams, such as municipal wastewater (Rotta et al., 2019), the anaerobically digested organic fraction of municipal solid waste (Oliveira et al., 2018), sourceseparated urine (Tarpeh et al., 2018) and pig manure (Shi et al., 2018), among others.

All ED-related technologies suffer from membrane fouling during wastewater nutrient recovery. The build-up of fouling layers increases cell resistance (current drop), reduces migration yield and ion selectivity and eventually alters membrane characteristics due to irreversible fouling. Different mechanisms can be used to reduce membrane fouling, such as periodically reversing the electrode polarity, reducing current density, improving hydraulic conditions in the stack compartment by increasing the flow rate or gasket with flow pattern, and in-place cleaning with acidic or basic solutions. Shi et al. 
(2019) achieved $\mathrm{N}$ recovery efficiency higher than $80 \%$ when treating pig manure digestate with electrodialysis reversal. Several authors have combined ED with struvite crystallization for simultaneous $\mathrm{NH}_{4}{ }^{+}$and $\mathrm{P}$ recovery, which resulted in reduced membrane scaling (Thompson Brewster et al., 2017).

\subsubsection{Bioelectrochemical systems}

BES technology uses the electrons produced during the oxidation of organics to produce energy and other value-added compounds. During electricity generation, $\mathrm{NH}_{4}{ }^{+}$ions are driven from the anode to the cathode to maintain charge neutrality. In the cathode chamber, $\mathrm{NH}_{4}{ }^{+}$is transformed into $\mathrm{NH}_{3}$ due to the high $\mathrm{pH}$ value. $\mathrm{NH}_{3}$ can be recovered from the cathode chamber via volatilization and subsequent absorption into an acid solution.

$\mathrm{NH}_{4}{ }^{+}$has been successfully recovered as $\mathrm{NH}_{3}$ in $\mathrm{BES}$ fed with different ammonium-rich wastewaters, such as synthetic wastewater, urine, swine wastewater and landfill leachate (Qin et al., 2016). Different mathematical models have also been developed to explain the ion transport mechanism taking place during $\mathrm{NH}_{3}$ recovery and $\mathrm{BES}$ operation (Recio-Garrido et al., 2016). Although $\mathrm{P}$ recovery has not been evaluated as much as $\mathrm{N}$ recovery, several authors have applied BES to recover $\mathrm{P}$ as struvite from different wastes, such as swine manure and urine (S. Lu et al., 2019). P can also be recovered from iron phosphate sewage sludge (Blatter et al., 2019). In this case, the electricity produced in the microbial fuel cell is used to reduce the $\mathrm{FePO}_{3}$ present in the digested sludge, dissolving precipitated phosphate into soluble forms, which can be recovered in the form of struvite in a subsequent crystallization process.

BES have been recently upgraded by integrating membrane technology, achieving improved energy recoveries and wastewater treatment efficiencies than conventional BES (Yang et al., 2019). For instance, Chen et al. (2017) developed an advanced microbial nutrient recovery cell for municipal wastewater treatment, achieving more than $95 \%$ recovery efficiencies in organic matter and nutrients. P recovery efficiency was around $60 \%$.

\subsubsection{AnMBR}

AnMBR is regarded as an energy-efficient and cost-effective system that can help shift wastewater treatment towards the CE. These systems consume less energy than aerobic-based processes, since 
oxygen is not needed for the recovery of organics, leading to a lower amount of biosolids to be handled and transforming biodegradable organics into the gaseous energy carrier $\mathrm{CH}_{4}$, suitable for energy production (Robles et al., 2018). Anaerobic digestion (AD) mineralizes organic $\mathrm{N}$ and $\mathrm{P}$ in the form of $\mathrm{NH}_{4}{ }^{+}$ and $\mathrm{PO}_{4}^{3-}$, allowing its recovery (e.g. struvite crystallization, microalgae cultivation, fertigation, etc.). Hence, negligible $\mathrm{N}$ and $\mathrm{P}$ removals (only microbial assimilation for biomass growth) are expected in AnMBR systems. The combination of $A D$ and membrane filtration has an intrinsic advantage: the inherent retention of pollutant solids, which results in excellent permeate qualities because of micron level filtration of the effluent, regardless of its initial quality (including microbiological decontamination by removing even viruses when the appropriate membrane cut-off is implemented). This effluent control quality facilitates nutrient recovery by different techniques.

Fertigation is another interesting option for nutrient recovery in AnMBRs. As previously commented, water scarcity and limited availability of essential nutrients represent a crucial risk to food production. Directly using the AnMBR effluent for fertigation purposes would alleviate not only water scarcities but also the dependence on chemical fertilizers, thus drastically improving the water-energy-food nexus (Lazarova et al., 2012). Moreover, fertigation would drastically reduce the environmental impact of AnMBR related to eutrophication (Pretel et al., 2016). However, when fertigation is not possible, AnMBR must be combined with a complementary post-treatment process for nutrient recovery, e.g. membrane contactors (Jacob et al., 2015), ion exchange (Calabria et al., 2019; Gu et al., 2019; Mai et al., 2018), or photosynthetic bioreactors (González-Camejo et al., 2019b; González et al., 2017; Seco et al., 2018; Viruela et al., 2018), among others.

\subsubsection{Direct filtration}

DMF can maximize the recovery of resources from wastewater by separating the soluble and suspended fractions of pollutants (Lateef et al., 2013). In this way, it is possible to increase the amount of nutrients that can be recovered from wastewater in a side-stream process. For instance, Lateef et al. (2013) showed that it is possible to recover about $75 \%$ of organics (including nutrients) from wastewater by DMF. These authors suggested that DMF could be used for retrofitting current wastewater treatment 
plants (WWTPs), maintaining the currently working footprints. Ravazzini et al. (2005) evaluated the performance of DMF technology for treating raw sewage and primary settler effluent for irrigation, showing its potential to produce high-quality nutrient-enriched water. However, only $10 \%$ of $\mathrm{N}$ and $20 \%$ of $\mathrm{P}$ were present in the reclaimed water produced in the main line. Ma et al. (2013) evaluated the recovery of organics from municipal wastewater by dynamic membranes and proposed an innovative concept for municipal wastewater treatment in which $\mathrm{N}$ and $\mathrm{P}$ recovery could be conducted on mainstream and sidestream, respectively.

Although DMF is a promising energy-efficient technology for concentrating organics from different streams (Sancho et al., 2019), there is still limited information regarding their feasibility for efficient fullscale implementation. Further research is needed on energy demand optimization and membrane fouling mitigation (Mezohegyi et al., 2012).

\subsection{Potentials and limitations}

Membrane processes are a promising technology to separate and/or concentrate nutrients in different streams. However, it is clear that there is great room for improvement in order to stimulate the competitive full-scale implementation of membrane-based technologies for resource recovery. In this respect, recent research mainly focuses on the optimization of membrane fouling and process economics. Membrane fouling is a big challenge for the recovery of nutrients from wastewater, since it deteriorates membrane productivity, increases power requirements and reduces economic feasibility (Yan et al., 2018).

The recovered nutrients can be directly or indirectly applied to agricultural purposes. For instance, the energy input of the filtration process in AnMBR or DMF technology for sewage treatment is commonly below $0.4 \mathrm{kWh}$ per $\mathrm{m}^{3}$ of treated water. Taking into account a wastewater with an ammonium concentration of $50 \mathrm{ppm}$, the cost of nitrogen recovery with the produced water would be below $8 \mathrm{kWh} \cdot \mathrm{kg}^{-1}$ $\mathrm{N}$. A key aspect to consider is the necessity of enhancing the process barrier against virus transmission (Amarasiri et al., 2017), especially in the case of water reclamation in agriculture (e.g. AnMBR or DMF). Similarly, the presence of pathogens in reclaimed waters is also responsible for some important health problems, and must therefore be adequately controlled and monitored. The use of membranes in the 
ultrafiltration range makes it possible to retain the pathogens and a large part of the viruses and represents a viable alternative for the regeneration of wastewaters. There are also indications of the competitive advantages of ultrafiltration systems for the mitigation of priority and emerging substances and persistent organic pollutants (Harb et al., 2019), including antibiotic-resistant bacteria (ARB) and antibiotic resistance genes (ARG) (Harb and Hong, 2017). However, further research is needed to validate the performance of long-term operations.

The combination of AnMBR with fertigation can be considered as a membrane-based technology for nutrient recovery 'ready' to be implemented for full-scale low-loaded wastewater treatment. However, this combination still faces technological and regulatory barriers that need to be solved. These bottlenecks were tackled within the Innovation Deal approved by the European Commission in 2016, dealing with AnMBR technology for low-loaded wastewater treatment, in which several case studies for water reuse were assessed (Jiménez et al., 2019, submitted). On the other hand, BES are one of the most promising membrane-based methods for nutrient recovery, although further research is needed from the laboratory context to pilot-scale scenarios in order to get enough information for scaling up BES to the industrial level. Furthermore, when applying BES to $\mathrm{P}$ recovery, struvite precipitation takes place on the cathode electrode and the collection of these precipitates and replacement/regeneration of the cathode electrode has not yet been solved.

HFMC seems to be a suitable option for $\mathrm{N}$ recovery from nutrient-rich streams (e.g. urine, swine manure or reject water in urban WWTPs) since the large towers required for $\mathrm{NH}_{3}$ stripping are replaced by small membrane devices, which have larger surface areas per volume of device unit. HFMC offers the prospect of being: selective to $\mathrm{NH}_{3}$ recovery, able to operate with lower energy inputs than other systems (e.g. air stripping), and highly selective of $\mathrm{NH}_{4}{ }^{+}$(Darestani et al., 2017).

The technical, economic and environmental viability of these membrane-based processes should be studied in depth for future full-scale implementation, taking into account not only power requirements and membrane fouling, but also other aspects such as the carbon footprint, system robustness, capital and expenditure costs, the quality of the generated product and market demands. 


\section{Photosynthetic-based systems for nutrient recovery}

\subsection{Photosynthetic-based technologies}

Photosynthetic wastewater treatment has also emerged as a sustainable and cost-effective alternative in the context of the CE (García et al., 2019).

One possible photosynthetic alternative is recycling nutrients from wastewater streams with microalgae cultures (Garrido-Cardenas et al., 2018; Santos and Pires, 2018), which has been reported to consume up to $24 \%$ less energy than conventional wastewater treatments and it is possible to recover up to $90 \%$ of the nutrients from wastewater effluents (Romero-Villegas et al., 2018). Indeed, in the last decade, there has been a noticeable scientific interest in microalgae-based technology for nutrient recovery from wastewaters (Judd et al., 2015), with a 20 -fold increase in the number of publications on microalgae research worldwide (Garrido-Cardenas et al., 2018). Several studies confirm that microalgae cultures successfully uptake N and P from different wastewater types (Guldhe et al., 2017), such as secondary effluent, primary clarifier effluent, AnMBR effluent, and AD supernatant, the effluents from farms mainly manure and centrate from anaerobic digestion of manure and other residuals. Moreover, using wastewater as nutrient substrate and flue gases as $\mathrm{CO}_{2}$ has emerged as a potential cost effective strategy for largescale microalgae production (Guldhe et al., 2017).

Photosynthetic bacteria (PSB) wastewater treatment has appeared as a novel technology that can perform wastewater treatment and nutrient recycling at the same time (Chen et al., 2019; H. Lu et al., 2019). Although, PSB has been used to treat some kinds of wastewaters since the 1960 s, mainly nontoxic industrial wastewaters, in the past ten years it has achieved increasing attentions due to its potential as a resource recovery technology (Meng et al., 2018). The application of PSB, mostly the purple nonsulfur bacteria (PNSB), has significant potential for sustainable wastewater treatment due to their high yield of hydrogen, their tolerance of toxicity and temperature fluctuations, and more versatile metabolic pathways than microalgae that can assimilate carbon (C), N and P in a single stage (González et al., 2017). PSB cells are not toxic and contain many high-value substances (carotenoids, coenzyme $Q$, vitamin $B$, nicotinic acid, pantothenic acid, protein, etc.) that can be used as fertilizers, animal feedstock 
and functional ingredients in agriculture and the food and medical industries (Chen et al., 2019). Thus, PSB wastewater treatment is economically and environmentally sustainable, not only because of nutrient recovery within the high value PSB cells but also due to the reduced sludge production.

A few studies have compared PSB resource recovery from wastewater and microalgae-bacteria consortia (García et al., 2019; Hülsen et al., 2018). The findings basically showed that although microalgae-based systems presented higher nutrient recovery efficiencies, PSB showed higher robustness versus dynamics in operating conditions.

Nutrient recovery efficiencies and valuable biomass productivity from photosynthetic-based systems generally depend on wastewater characteristics, process technology, phototrophic organisms and environmental/operating conditions.

\subsubsection{Microalgae-based technology}

A large number of algal species have been used in wastewater treatment. Many authors have evaluated pure microalgae cultures, but in large scale outdoor conditions, the mixed microalgae culturesbacteria consortia is what naturally occurred (Gonçalves et al., 2017; González-Camejo et al., 2019a). Different microalgal-bacterial consortia are obtained according to the wastewater characteristics and environmental and operating conditions. This symbiosis favors low energy consumption and carbon footprint since the $\mathrm{CO}_{2}$ generated during heterotrophic organic matter degradation is photosynthetically fixed and the oxygen required to degrade the organic matter is released by the microalgae (Uggetti et al., 2018). The relative importance of these processes $\left(\mathrm{O}_{2}\right.$ production, $\mathrm{CO}_{2}$ production, nutrient fixation, etc.) is based on the composition of the consortium (Acién Fernández et al., 2018). In this respect, microorganisms such as nitrifying bacteria compete with microalgae for nutrients, affecting the $\mathrm{N}$ recovery potential of the process. Particularly, nitrifying bacteria can reduce microalgae growth by depleting the ammonium concentration in the media, hence limiting microalgae $\mathrm{N}$ uptake, thus reducing nitrogen recovery (González-Camejo et al., 2019b; Viruela et al., 2018). In addition, nitrifying bacteria oxidize the ammonium to nitrite which has been reported to negatively affect microalgae, in spite of also being a nitrogen source for microalgae growth. 
Green microalgae genera (e.g.Chlorella sp., Monoraphidium sp. and Scenedesmus sp.) have been extensively reported as ideal for wastewater treatment due to their adaptability to this medium (K. Li et al., 2019; Vo et al., 2019). Other authors have used cyanobacteria instead of green algae because of their ability to produce metabolites such as phicobiliproteins and polyhydroxybutyrates. Cyanobacteria are easier to digest due to their soft cell wall (Arias et al., 2017). In contrast, nutrient uptake efficiencies are usually lower than those for green algae. Autotrophic, heterotrophic and mixotrophic metabolism for microalgae-based cultivation can be found, in which biomass anabolism is carried out by fixing $\mathrm{CO}_{2}$ with an energy input from either light or an external inorganic electron donor, by organic carbon sources without light, or alternatively, according to the operating conditions (K. Li et al., 2019). Although heterotrophic metabolism has huge advantages, such as growth in dark conditions (Turon et al., 2016), microalgae are primarily photosynthetic and only a few are facultative heterotrophs (K. Li et al., 2019). Microalgae-based wastewater treatment depends on many factors (Guldhe et al., 2017; Vo et al., 2019), some of them related to environmental conditions (outdoor/indoor, light, temperature, etc.), wastewater characteristics (C:N:P ratio, nutrient levels, toxics..) and others associated with operating conditions (batch/continuous, $\mathrm{CO}_{2}$ addition, hydraulic and solids retention time, mixing, $\mathrm{pH}$ etc ) and reactor configuration (light path, open systems, photobioreactor, attached-growth, etc.).

The factor that most affects nutrient recovery efficiency and biomass productivity is the average irradiance of the cells, which is a function of the light available and water depth. Shallow depths are used to increase performance yields and greater depths to increase treatment capacity (Acién Fernández et al., 2018). This means a difficult trade-off must be made to optimize reactor design. In addition to light intensity, light frequency and photoperiods have also been assessed in the literature (González-Camejo et al., 2019b).

The photobioreactor design is another important factor for achieving both cost-effective and highefficiency wastewater treatment. Basically, they can be classified into open systems, closed photobioreactors and newly designed hybrid photobioreactors (K. Li et al., 2019; Vo et al., 2019). Mainly for cost-effective reasons, the most frequently used system for wastewater treatment is the open pond 
reactor, which consists of a shallow depth carrousel $(15-40 \mathrm{~cm})$ in which the water is recirculated by paddlewheels (Arbib et al., 2017). The key issue in this technology is process control, since it is significantly affected by ambient factors, $\mathrm{N}$ and $\mathrm{CO}_{2}$ losses and the large surface areas required (X. Xu et al., 2019). Different configurations of closed photobioreactors have been widely reported: tubular, flat panel, vertical columns, soft frame and hybrid photobioreactors. The increasing interest in optimizing and assessing new photobioreactor configurations is based on developing a high-efficiency treatment system that reduces their typical high investment and operating costs (Vo et al., 2019). In this respect, hybrid systems have been proposed such as membrane photobioreactors in which biomass and hydraulic retention times can be decoupled, enabling higher efficiencies (González-Camejo et al., 2019b). Another recent hybrid technology is microalgae biofilms, with different attached materials and reactor designs (Gross et al., 2015).

Microalgae-based processes for the recovery of nutrient from wastewater can be divided into the following steps: (i) pre-treatment, (ii) nutrient uptake and biomass production, (iii) biomass harvesting, and (iv) transformation of the biomass into end products. Harvesting microalgae is a challenging step due to the low recovery efficiencies of some technologies and their high capital and operating costs (Alkarawi et al., 2018). Separation of microalgae biomass is attained by gravity sedimentation, flocculation, flotation, centrifugation, filtration or a sequence of any of these. When recovering nutrients from wastewater, only low energy-demanding and cost-effective technologies must be considered. Centrifugation is the most widely used (Acién Fernández et al., 2018) and membrane filtration appears as one of the most competitive separation methods (Judd et al., 2015). Depending on the final application, a dewatering step is also required, such as sun-drying, drum drying, etc. The final step involves biochemical (anaerobic digestion, alcoholic fermentation, transesterification, etc.) or thermochemical processes (pyrolysis, hydrothermal carbonization, etc.) (Santos and Pires, 2018).

Producing microalgae from wastewater allows the recovery of nutrients as valuable biomass, obtaining from $1 \mathrm{~kg}$ to more than $10 \mathrm{~kg}$ of dry microalgae per cubic meter of sewage and manure, respectively (Acién Fernández et al., 2018). This valuable biomass can be used for non-human related applications, 
i.e. energy, livestock (aquaculture and animal feeding) or agricultural uses. Valuable compounds such as pigments, omega fatty acids, proteins, vitamins, etc. can be synthesized from microalgae biomass (Garrido-Cardenas et al., 2018) and it can be converted into renewable energy source such as biogas, biodiesel, bioethanol, biohydrogen, etc. (Guldhe et al., 2017). In all the different options related to biofuel production, the harvesting and dewatering step plays a key role, since it is a very energy-demanding process and accounts for around 3-15\% of the total production costs of microalgae biomass (Fasaei et al., 2018). In nutrient recovery, microalgae biomass can also be used as fertilizer for the agricultural industry (Marazzi et al., 2019). In this application, downstream processes are also crucial, such as harvesting and dewatering, for instance, using biomass as a bio-char for hydrothermal carbonization (HTC). Using wet biomass appears as a promising solution as it eliminates drying costs (Santos and Pires, 2018).

\subsubsection{Photosynthetic-bacteria-based technology}

PSB can be classified into four main families: PNSB, purple sulfur bacteria (PB), green sulfur bacteria (GSB) and gliding filamentous green sulfur bacteria (GFB). PNSB is the most widely reported for wastewater treatment due to their more versatile metabolism. They assimilate organic compounds as e.g. polyhydroxybutyrate (PHB) but also recover nutrients by inorganic polyphosphate (poly-P) formation and $\mathrm{N}$ by denitrification and assimilation (Hülsen et al., 2014). C, N and P are assimilated in 13\%-99\%, 22.0\%$98.2 \%$ and $64.7 \%-96.1 \%$, respectively, (H. Lu et al., 2019) in a single stage and then concentrated in the biomass phase for subsequent recovery (Hülsen et al., 2016). PSB-based treatment processes mainly depend on light-oxygen conditions (photoperiods, infrared light intensity, etc.), pH, trace-level elements and C:N ratios (Zhou et al., 2015). There are significant lab-scale studies for easily-biodegradable loaded wastewaters (500-40,000 mg $\left.\mathrm{L}^{-1}\right)$, mostly from food and alcohol processes (H. Lu et al., 2019; Meng et al., 2018), while a few more recent works deal with the application to domestic wastewater (González et al., 2017; Hülsen et al., 2016, 2014). However, the need for more favorable C:N:P ratios such as those found in industrial wastewaters is a key limiting factor (Hülsen et al., 2016; H. Lu et al., 2019).

The PSB-based process for nutrient recovery from wastewater is divided into the following steps: (i) pre-treatment, (ii) PSB growth with/without inoculation, (iii) PSB separation and (iv) downstream process 
(H. Lu et al., 2019). Pretreatment such as pre-fermentation is required, since PSB can only utilize micro organic molecules (organic acids, alcohols and some sugars), after which a proper reactor configuration is applied to favor PSB growth and the assimilation of $\mathrm{C}, \mathrm{N}$ and $\mathrm{P}$ in a single stage (most of the studies inoculated PSB directly into the wastewater). Photobioreactor technology is the one most frequently applied and coagulation and centrifugation are the common PSB separation processes used. Due to the poor settling properties of PSB, membrane downstream process photobioreactors are now being studied (González et al., 2017). There have also been recent advances in additives for enhancing PSB wastewater treatment with promising results in both treatment efficiency and yield of high-value substances (Chen et al., 2019).

Table 1 gives some recent examples of average biomass productivities and nutrient recovery efficiencies for the different reactor configurations and photosynthetic-based systems found in literature.

\subsection{Potentials and limitations}

Both photosynthetic-based systems are promising alternatives for nutrient recovery from wastewater, not only due to their ability to assimilate nutrients and their smaller carbon footprint than conventional technologies, but also because of the high-value biomass produced with competitive yields (see Figure 2). Microalgae biomass can be used for energy, livestock or agriculture, in aquaculture, as a soil additive and bio-chemical raw materials. However, further safety criteria need to be drawn up for the utilization of PSB biomass obtained from wastewater (H. Lu et al., 2019).

There are still remaining challenges that often make the up-scaling of photosynthetic-based technologies to outdoor conditions uncertain, entailing both cost-effectiveness and high-efficiency. Indeed, PSB-based technology still remains at the indoor lab applications level, in contrast to the widespread application of microalgae cultivation (García et al., 2019; H. Lu et al., 2019). In this respect, further improvement of the available technologies is required, the main issues being reducing the space requirements and operating costs, maximizing light availability and biomass separation. As microalgae and PSB are difficult to harvest from the wastewater, more efficient and cost-effective technologies than the traditional ones (coagulation-flocculation) are being investigated, such as membrane photobioreactors, 
photo-granular processes, biofilm, additives and so on. So far, the land requirements of the current photosynthetic-based technologies limit their application for nutrient recovery from industrial wastewater, and also tertiary sewage treatment for microalgae-based technologies. PSB-based systems must be adapted to treat sewage since they require a supplementary carbon addition, which currently makes them unable to recover $100 \%$ of the nutrients from sewage (ideal C:N:P ratio close to $100: 6: 1$ ).

Another challenging task is the development of reliable mathematical models, since so far few have been reported (Puyol et al., 2017). These models would help to clarify the performance of phototrophic organisms and their interaction with other microorganisms. Cost and environmental life cycle assessment studies are also scarce, even for microalgae-based systems. These would help to assess the economic and environmental feasibility of photosynthetic-based systems for different wastewater sources and different application scenarios.

\section{4. rystallization-based systems for nutrient recovery}

\subsection{Crystallization-based technologies}

Over 30 processes for $P$ recovery from wastewater treatment plants have now been identified and tested on different scales (Cieślik and Konieczka, 2017), including phosphate salts precipitation/crystallization, which at present is one of the most promising technologies for recovering $\mathrm{P}$ and $\mathrm{N}$ in wastewater treatment plants (B. Li et al., 2019a; Lu et al., 2017; Peng et al., 2018), achieving a technology readiness level (TRL) of 7 or above (B. Li et al., 2019b). Unlike other nutrient recovery processes (biological, electrochemical, ion exchange, or membrane systems), struvite crystallization shows notable recovery rates with acceptable economic efficiency and generates a marketable product with a limited environmental impact (Peng et al., 2018).

Struvite crystallization can remove between 80 and $90 \%$ of $\mathrm{PO}_{4}^{3-}$ and a lesser percentage of $\mathrm{NH}_{4}{ }^{+}(20-$ $30 \%$ ) due to the equimolar stoichiometry of struvite (Le Corre et al., 2009). P recovery rates improve when streams with a low solids content $\left(<2000 \mathrm{mg} \mathrm{L}^{-1}\right)$ and $\mathrm{P}$ concentrations higher than $50-60 \mathrm{mg} \mathrm{P}-\mathrm{PO}_{4} \mathrm{~L}^{-1}$ are treated (Mehta et al., 2015; Salehi et al., 2018). P recovery by crystallization could thus be carried out directly from different P-concentrated waste flows such as urine, thickener supernatant, digester supernatant or 
even industrial effluents (mainly agro-food processing industries). Table 2 gives examples of many $P$ recovery technologies on lab, pilot or industrial scales with information on wastewater characteristics, magnesium source for $\mathrm{P}$ recovery, reactor types, recovery efficiencies and characteristics of the struvite obtained.

\subsubsection{Struvite}

Struvite is magnesium ammonium phosphate $\left(\mathrm{MgNH}_{4} \mathrm{PO}_{4} \cdot 6 \mathrm{H}_{2} \mathrm{O}\right)$ and is usually found precipitated on metal surfaces during anaerobic digestion and dewatering in wastewater facilities (Ohlinger et al., 1998). These precipitation problems lead to high maintenance costs and also reduce the amount of $P$ recovered from WWTPs. This uncontrolled precipitation, along with struvite's potential as a fertilizer, have encouraged the development of many technologies for nutrient recovery, such as struvite from wastewater (Cieślik and Konieczka, 2017; Le Corre et al., 2009). WWTPs present a good opportunity for P recovery due to the relatively high and constant nutrient load in sewage.

Crystallization consists of a two-step process (nucleation and crystal growth) controlled by a combination of physical-chemical parameters. Temperature, $\mathrm{pH}$ and supersaturation of the solution, mixing energy and the presence of foreign ions such as calcium are key parameters in the crystallization process (Pastor et al., 2010). Great efforts have been made by researchers to study nutrient recovery from different streams, such as landfill leachate (Huang et al., 2014), centrate (Lahav et al., 2013; Pastor et al., 2010) or sourceseparated human urine (Aguado et al., 2019; Dai et al., 2014), among others (Peng et al., 2018; Yetilmezsoy et al., 2017).

However, the number of industrial scale applications is small due to gaps and shortcomings such as product quality, economic feasibility or the legal framework (B. Li et al., 2019a; Yetilmezsoy et al., 2017).

\subsubsection{Vivianite}

Although struvite crystallization for $\mathrm{P}$ recovery has been broadly adopted in Europe and North America, there are some aspects that hinder its recovery as struvite: (1) high-cost low-value products; (2) complex operating conditions (pH 8.0 - 9.5); (3) low recovery efficiency (10-50\%) and (4) the need for an enhanced biological P recovery (EBPR) system already implemented in the WWTP (Wu et al., 2019). P recovery as 
vivianite $\left(\mathrm{Fe}_{3}\left(\mathrm{PO}_{4}\right)_{2} \cdot 8 \mathrm{H}_{2} \mathrm{O}\right)$ has been studied mainly due to its predictable economic value and its natural abundance.

Iron $(\mathrm{Fe})$ is present in natural water due to the presence of dissolved iron minerals. In wastewater, as the Fe ions usually come from the Fe salts used as flocculants to chemically remove $P$, using this $F e$ to precipitate $\mathrm{P}$ could be a good choice.

Using vivianite as a fertilizer is four to six more efficient than calcium phosphate, but not more efficient than struvite or hydroxyapatite. As hydroxyapatite, vivianite is a slow-release fertilizer, but vivianite can also mitigate chlorosis caused by iron deficiency (Díaz et al., 2010) which is an advantage over struvite or hydroxyapatite.

An important vivianite application is the production of $\mathrm{LiFePO}_{4}$, an essential compound in the manufacture of Li-ion batteries (Priambodo et al., 2017). This means the demand for vivianite is likely to increase steadily over the next few years in the hybrid and electric car industries.

For all the above reasons, vivianite formation from $\mathrm{P}$ recovered from wastewater is not only a way of avoiding P depletion, but also offers potential economic opportunities (Wu et al., 2019), as it achieves high market prices (approximately $€ 10,000$ per ton), much higher than that of struvite (€100-500 per ton) (Peng et al., 2018; Wu et al., 2019).

Despite the advantages of recovering $P$ as vivianite, some of the drawbacks should be highlighted: (1) vivianite is formed in the sludge phase as crystals or aggregates between 10 and $150 \mu \mathrm{m}$, which are difficult to separate from sludge; (2) vivianite particles usually contain impurities (i.e. magnesium or calcium). In contrast to pure vivianite, which can be stable for several weeks, impure vivianite is oxidized within $48 \mathrm{~h}$ (Wilfert et al., 2018), and vivianite separation and purification methods are not yet well developed. Some of the outstanding separation methods studied include: (1) a few works on crystallization, (2) magnetic separation, which has high energy demands (Frederichs et al., 2003), and (3) centrifugation based on the different densities of sludge and vivianite (1 and $2.68 \mathrm{~g} / \mathrm{cm}^{3}$ respectively). Removing the organic matter mixed with vivianite is also a challenge (Wu et al., 2019).

\subsubsection{Other precipitates}


Most processes for $\mathrm{P}$ recovery from wastewater produce struvite. However, the lack of $\mathrm{N}$ in industrial wastewater can be a limiting factor for struvite production. For example, wet phosphoric acid production plants can precipitate hydroxyapatite and then put it back into the process itself (Cichy et al., 2019) or even use it for fertilizer production. Apart from struvite and vivianite, at least nine other phosphate precipitates have been described in WWTPs: newberyite $\left(\mathrm{MgHPO}_{4} \cdot 3 \mathrm{H}_{2} \mathrm{O}\right)$, dittmarite $\left(\mathrm{MgNH}_{4} \mathrm{PO}_{4} \cdot \mathrm{H}_{2} \mathrm{O}\right)$, bobierrite $\left(\mathrm{Mg}_{3}\left(\mathrm{PO}_{4}\right)_{2} \cdot 8 \mathrm{H}_{2} \mathrm{O}\right)$, monenite $\left(\mathrm{CaHPO}_{4}\right)$, amorphous calcium phosphate $\left(\mathrm{Ca}_{3}\left(\mathrm{PO}_{4}\right)_{2} \cdot \mathrm{nH}_{2} \mathrm{O}\right)$, brushite $\left(\mathrm{CaHPO}_{4} \cdot 2 \mathrm{H}_{2} \mathrm{O}\right)$, hydroxyapatite $\left(\mathrm{Ca}_{5}\left(\mathrm{PO}_{4}\right)_{3}(\mathrm{OH})\right), \quad$ K-struvite $\left(\mathrm{MgKPO}_{4} \cdot 6 \mathrm{H}_{2} \mathrm{O}\right)$ and Na-struvite $\left(\mathrm{MgNaPO}_{4} \cdot 6 \mathrm{H}_{2} \mathrm{O}\right)$. Of these, the last five have been most widely studied and are a viable alternative for wastewaters with low $\mathrm{NH}_{4}+$ content (Delgadillo-Velasco et al., 2020; Huang et al., 2019). Calcium phosphates, especially hydroxyapatite, have lower agronomic characteristics ( $P$ release for plants) than struvite or vivianite, which limit its selling price.

\subsection{Potentials and limitations}

Phosphate salt precipitation/crystallization seems appropriate for recycling nutrients such as $\mathrm{N}$, magnesium, calcium, but mainly P. Precipitate phosphate salts can be used as a direct fertilizer or as precursors or intermediates for fertilizer manufacturing (e.g. superphosphates or di-ammonium phosphates) to mitigate the future scarcity of raw materials for traditional fertilizer production. Struvite can also be used as raw material for several chemical industries (food additives, fire-retardant agents or construction products.

Despite the implemented $\mathrm{P}$ crystallization recovery systems appear to be technically and even economically feasible, as has demonstrated by various commercial processes for $\mathrm{P}$ and $\mathrm{N}$ recovery (Egle et al., 2016, 2015; Melia et al., 2017). Further work should focus on: increasing $P$ availability for crystallization by enhancing organic $P$ release and $P$ extraction before digestion units, improving the economic balance of the $\mathrm{P}$ recovery process, testing the fertilizing properties of the struvite produced, and promoting the legal framework and social acceptance of wastewater-derived products.

$P$ recovery by struvite crystallization in the liquid phase (i.e. secondary treated effluent, digester supernatant, thickener supernatant or separated urine stream) produces better quality fertilizing materials 
than $P$ recovered from sewage sludge ash (SSA). However, the $P$ recovery rates $(<25 \%$ relative to the WWTP input) are relatively low in comparison with those achieved in SSA ( $~ 40-50 \%$ relative to the WWTP input) (Egle et al., 2016). In order to enhance the relatively low $P$ recovery rates from liquid phase streams, optimized WWTP P management is required. For example mathematical modeling has proved to be crucial for assessing different operating P recovery optimization strategies in WWTPs (Lizarralde et al., 2019; Martí et al., 2017). In full-scale WWTPs with an EBPR process, over $85 \%$ of $P$ in municipal wastewater influent is transferred into the sewage sludge (Melia et al., 2017; Tarayre et al., 2016) as poly-P inside the polyphosphate accumulating organisms (PAO). The poly-P is then released into the liquid phase during anaerobic sludge digestion and thus high $\mathrm{P}, \mathrm{NH}_{4}{ }^{+}$and magnesium concentrations are reached in the rejected liquors from sludge dewatering. The high-concentrate streams are very suitable for $\mathrm{P}$ crystallization (Pastor et al., 2010: Lahav et al., 2013). However, most of the potentially soluble P can be re-fixated throughout the sludge line due to uncontrolled precipitation with $\mathrm{Fe}, \mathrm{Al}, \mathrm{Ca}$, and $\mathrm{Mg}$ or through adsorption on the surface of solids (Barat et al., 2009; Marti et al., 2008). Some studies have proposed modifications of the sludge line configuration to promote $\mathrm{PO}_{4}{ }^{3-}$ extraction previous to the digestion process by means of: including a redissolution tank (Lizarralde et al., 2019), elutriation in the gravity thickener of the mixing chamber sludge (Bouzas et al., 2019; Martí et al., 2017) or including an anaerobic holding tank coupled to a thickening centrifuge (Cullen et al., 2013). These strategies have been shown to be useful for reducing uncontrolled $\mathrm{P}$ precipitation by $43-45 \%$, sludge disposal by $5.1-6.6 \%$ and obtaining a two-fold increase in $\mathrm{P}$ available for crystallization. However, around $50 \%$ of $P$ in the sludge line from organic matter degradation is still lost by precipitation inside anaerobic digesters (Bouzas et al., 2019), which offers a great opportunity for improving $P$ recovery.

The chemical cost has been identified as one of the major items of the global P recovery process via struvite crystallization (B. Li et al., 2019a). The costs, without savings and revenues, of struvite crystallization $P$ recovery systems are approximately $€ 6$ to $€ 10$ per $\mathrm{kg}$ of $P$ recovered, or 0.8 to $€ 1.7$ PE per year (Egle et al., 2016). Moreover, as previously mentioned, reduced P concentration in the crystallizer inlet significantly increases the overall process cost. Regarding the main direct benefits of selling struvite, reduced dewatered 
sludge disposal as well as polyelectrolyte consumption must be considered (Egle et al., 2015). The economic analyses carried out to assess the feasibility of several $\mathrm{P}$ crystallization technologies in wastewater treatment plants show that the revenue from P recovery is small (Egle et al., 2016; B. Li et al., 2019b; Peng et al., 2018), but a specific case-by-case analysis should be done, since different boundary conditions may determine the economic payback from $\mathrm{P}$ recovery. When economic reasons are weak, governments should encourage $P$ recovery by providing incentives to recover products by means of legislation.

Some countries have introduced legislation to enforce $P$ recovery from wastewater, as in Switzerland, the first to make $P$ recovery mandatory from sewage sludge and slaughterhouse waste, and others such as Sweden, Austria and Germany have followed suit (Günther et al., 2018).The current legal framework for recovery of phosphate salts varies across the different EU Member States. Precipitated phosphate salts can be legally used as fertilizers in the Netherlands, Belgium, Germany, France, Denmark and the UK. The European Commission has recently revised EU legislation on fertilizers (EU Fertilizing Products Regulation (EU) 2019/1009), expanding its scope to secondary-raw-material-based fertilizing products. The goal is to assess a future legal framework for the production of safe and effective fertilizers from recovered, secondary raw materials, such as struvite, ashes and biochar (Huygens et al., 2019) and opens up the possibility of boosting nutrient recovery from wastewater.

\section{Other systems for nutrient recovery}

\subsection{Other physical and biological technologies}

Despite the different methods evaluated to recover nutrients from the different sidestreams obtained during sludge management (centrates from digested sludge, thickeners overflows, etc.), a large amount of nutrients still remain in the sludge at the end of the process (Bouzas et al., 2019). A number of studies have focused on the evaluation of potential nutrient recovery from final WWTP waste sludge by different techniques such as composting, incineration, etc.

\subsubsection{Incineration}

Incineration is a sludge oxidation process resulting in a gas stream mainly composed of $\mathrm{CO}_{2}$ and $\mathrm{H}_{2} \mathrm{O}$, 
ash and heat. One of incineration's main advantages is the reduced sludge volume (around 90\%) and the complete removal of pathogens. Traditionally, the ash (around $30 \mathrm{wt} \%$ ) is disposed of in landfills or used in the construction sector, while the heat energy is recovered as power with turbines (Raheem et al., 2018).

However, incineration of waste activated sludge (WAS) is now being applied in more countries due to the strict legal requirements imposed on the land application of WAS for food production (Mailler et al., 2014). The ashes are composed of highly concentrated $P$, mainly due to the considerably reduced volume. While WAS P content varies from 1 to $5 \%$, this content rises to $5-11 \%$ in ashes (Ottosen et al., 2013). Couto et al. (2015) observed that the $P$ concentration in sewage sludge is around $0.12 \mathrm{~g} / \mathrm{L}$, while the ashes from its incineration may contain from 70 to $134 \mathrm{~g} / \mathrm{kg}$. However, the high percentage of heavy metals and the low $\mathrm{P}$ accessibility in agriculture is often a problem associated with incineration (Ottosen et al., 2013). For this reason, different studies have focused on the development of ash management strategies to upgrade incineration ashes (Raheem et al., 2018), including: thermal treatment with polyvinylchloride (PVC) and magnesium oxide (MgO), acid leaching, and electrodialysis. It is remarkable the improvements of thermal treatment with PVC over the quality of the incineration ashes. During this technic the sludge ashes are thermochemically treated with PVC removing the heavy metals present in the ashes via the chloride pathway (Vogel et al., 2013). On the other hand, this process allows to use the PVC not recycled during the solid waste management, as a source of $\mathrm{Cl}$.

\subsubsection{Sludge composting and direct land application}

According to Eurostat, during the last decade approximately $40 \%$ of the sludge produced in the EU was used for agriculture and composting (Gherghel et al., 2019). Traditionally, the direct agricultural application of wastewater sludge has been the simplest method of nutrient recycling, this being one of the classical preferred options due to the recoverable sludge nutrients content (Fijalkowski et al., 2017). However, this method has now been limited or even banned in many European countries (Cieślik and Konieczka, 2017; Egle et al., 2015) due to the environmental risks associated with heavy metals, persistent organic pollutants and sludge pathogen content. Nutrient recovery technologies, which guarantee the safety of the product obtained, are thus required. 
Composting involves the treatment and conversion of sewage sludge into a stabilized product that can be applied to land as organic fertilizer or a value-added product (Anjum et al., 2016).

Although the sludge characteristics required for use in agriculture and compost are regulated in the Sewage Sludge Directive and by the requirements for organic fertilizers, one of the aspects that is raising interest and concern is the presence of ARGs and ARB in the final product (Xue et al., 2019). Their presence is due to the high worldwide antibiotics consumption, which are partially metabolized and released unchanged into the environment, contributing to the growth and accumulation of ARB and ARGs (Yang et al., 2018). Antibiotics usually reach the WWTPs through the sewage network, making them a hotspot for ARB and ARG accumulation, mainly in the sludge (Xue et al., 2019). It is thus important to consider how ARB and ARG treatment affects the different sludge processes, especially those aiming at preparing sludge for land applications (e.g. composting). Regarding this aspect, Bao et al. (2020) observed that the addition of microporous adsorption resin during the composting process reduces the risk of ARG transmission.

\subsubsection{Ammonia stripping and absorption}

$\mathrm{NH}_{3}$ stripping and absorption is a physico-chemical process in which $\mathrm{NH}_{3}$ is favored modifying the thermodynamic equilibrium of $\mathrm{NH}_{3} / \mathrm{NH}_{4}{ }^{+}$in the liquid to be treated, increasing the temperature $\left(60-80^{\circ} \mathrm{C}\right)$ and/or the $\mathrm{pH}$ (8-12). The $\mathrm{NH}_{3}$ dissolved in the liquid is transferred to the air stream, which can be later absorbed in a solution of sulfuric acid in an air scrubbing unit, where ammonium sulfate is generated. Many lab- and pilot-scale research projects have studied the effect of the operating conditions (air flow rate, temperature, $\mathrm{pH}$, etc-) on stripping efficiency and have reported success in $\mathrm{NH}_{3}$ stripping and absorption in different wastewater sources (Bousek et al., 2016; Campos et al., 2013; Pedizzi et al., 2018; Serna-Maza et al., 2015). Variants have also been proposed, like the novel process for $\mathrm{NH}_{3}$ recovery coupling vacuum thermal stripping with acid absorption developed by Ukwuani and Tao (Ukwuani and Tao, 2016). In this process, $\mathrm{NH}_{3}$ is stripped from anaerobic digestion effluent using a temperature below boiling point by a vacuum-driven force. These authors have shown on a pilot scale that crystals of highpurity ammonium sulfate can be obtained by adjusting the content of sulfuric acid and keeping the acid 
solution saturated with ammonium sulfate. Full-scale applications of $\mathrm{NH}_{3}$ stripping and absorption process have also been reported in different parts of the world. Jamaludin et al. (2018) tested alternative scrubbing agents (chilled water, mineral salts and organic acids) for $\mathrm{NH}_{3}$ recovery, to avoid the use of sulfuric acid, normally restricted in small municipalities due to to safety and environmental concerns. They identified citric acid as the most sustainable and efficient scrubbing agent to obtain an organic biofertilizer (ammonium citrate) when reacting with the stripped $\mathrm{NH}_{3}$ gas.

Additional advantages, like odor removal and the production of biofertilizers can make the $\mathrm{NH}_{3}$ stripping and absorption process more attractive in regions with a notable $\mathrm{N}$ demand than other technologies that are in theory cheaper for $\mathrm{NH}_{3}$ removal (e.g. anammox process). The effluent discharged from the stripping process usually presents high $\mathrm{pH}$ and alkalinity, which could adversely affect the receiving aquatic environment (Lyu et al., 2018). To avoid this, a post-neutralization step could be implemented prior to the effluent discharge, increasing the operating costs and the complexity of the treatment train.

\subsubsection{Emerging enhanced nutrient recovery}

\subsubsection{Conversion of non-reactive $P$ into reactive $P$}

To maximize P recovery, Venkiteshwaran et al. (2018) have recently highlighted the need to unlock the unavailable pool of non-reactive $P(N R P)$. The NRP fraction includes organic and inorganic $P$ and can be in soluble form (e.g. polyphosphates, parathion, DNA, Glyphosate, etc.) or particulate form (e.g. intracellular polyphosphates, iron phosphate precipitates, etc.). However, full P characterization is rarely performed and reported, being in most cases only total phosphorus (TP) and soluble reactive phosphorus (sRP) reported. This limited $\mathrm{P}$ characterization prevents a complete understanding of its environmental fate, as well as the design of effective strategies for $P$ mitigation and recovery (Venkatesan et al., 2018). Different pathways such as redox and hydrolysis have been identified as possible mechanisms for NRP conversion to RP. This conversion can be accelerated or even initiated via thermal, biological or physicchemical processes. The data that will allow selecting the most appropriate NRP conversion technology for each application does not yet exist. For high-organic wastes, organically bound $\mathrm{P}$ release via 
hydrolysis can be accomplished together with the energy recovery of the organic content in the anaerobic digestion process. Once $\mathrm{P}$ is present as phosphate, it can be captured in a reusable form (Rittmann et al., 2011). Effective thermal conversion of polyphosphates to SRP has also been demonstrated at lab, pilot and full-scale. However, the effect of heat on the release of other NRP components is still lacking.

\subsubsection{Innovative $P$ recovery processes combined with granular sludge systems}

High volumetric loading capacity and microbial retention capacity make granular sludge processes attractive. Biologically induced phosphorous precipitation has been reported in these granular systems (Johansson et al., 2017), giving rise to combined systems as a new alternative for P recovery. Ma et al. (2018) have recently proposed a process that simultaneously allows both $\mathrm{P}$ recovery and $\mathrm{N}$ recovery through combining two processes in an expanded bed reactor: anammox and hydroxyapatite precipitation. The lab-scale reactor was operated for $81 \mathrm{~d}$, obtaining a granular sludge with high P content (over 13\%), with anammox bacteria predominating in the outer layer of the granules, while a homogenous calcium phosphate matrix was present within the granules (in the inner core). The long-term operation has recently been evaluated (Lin et al., 2019) and some practical application guidelines for the coupled process have been established from the results,.

\subsubsection{Innovative $P$ recovery processes associated with sulfur cycle}

Sulfur is one of the most important elements in nature. Sulfur can be found as gypsum $\left(\mathrm{CaSO}_{4}\right)$, metal sulfide $\left(\mathrm{FeS}_{2}\right)$ and elemental sulfur $\left(\mathrm{S}_{0}\right)$ and in seawater as sulfate $\left(\mathrm{SO}_{4}{ }^{2-}\right)$. One potential application of sulfur in the transition towards the concept of biorefinery is the combination of biological sulfur oxidation with biological phosphorous recovery. Different studies have observed that a group of sulfur oxidizing organisms (SOO), such as the Thiomargarita, Thioploca and Beggiatoa genera, show a similar metabolism of PAO. This group of $\mathrm{SOO}$ is able to uptake sulfide and store it intracellularly as elemental sulfur as an energy source jointly with polyphosphate. Wu et al. (2014) proposed a sulfur cycle-associated with EBPR, in which SOO (e.g. Thiohalomonas, Thiotrichaceae and Thiobacillus) use sulfur and poly-P as the energy source to perform biological P recovery (Guo et al., 2016). According to Rubio-Rincón et al. (2017), the presence of Thiothrix caldifontis enhances $P$ removal in wastewaters with low organic matter 
concentrations rich in sulfide.

\subsubsection{Nutrient recovery via adsorption and ion exchange}

Different materials can be used to adsorb nutrients from the liquid stream to be treated, such as activated carbon, bio-char and zeolites. Adsorption processes can highly concentrate nutrients from the liquid stream in the adsorbent. In these processes, nutrients are attracted from the liquid to the surface of the adsorbent where they are held by intermolecular forces. One of the main advantages of ion exchange is that it offers an approach to jointly remove and recover nutrients after adsorbent regeneration. The adsorption capacity of renewable adsorbents such as different types of bio-char (which can be produced from different wastes), has received considerable attention in the last decade (Huong et al., 2019). In addition to the porous carbon structure, abundance of surface functional groups and high specific surface area, their natural properties can be modified to improve the adsorption capacity of anions. For example, the affinity for $\mathrm{PO}_{4}{ }^{3-}$ has been increased in lanthanum-modified adsorbents. Lab-scale studies have demonstrated high adsorption capacities (which are significantly reduced in the presence of competing anions) together with notable desorption and regeneration capabilities (Huong et al., 2019; Q. Xu et al., 2019). Regeneration of the adsorbent is essential for proper operation in industrial applications. Different approaches have been described and applied for the regeneration of the adsorbents, including elution with (1) $1 \mathrm{M} \mathrm{NaOH}$ solution for 2-3 h at room temperature, (2) $6 \mathrm{M} \mathrm{HCl}$ solution and (3) a mixed solution of $\mathrm{NaOH}(15 \mathrm{wt} \%)-\mathrm{NaCl}(5 \mathrm{wt} \%)$. Then, the regenerated adsorbent is washed with deionized water getting ready to be used for the next reuse-regeneration cycle.

Solid phase zeolites are currently being applied in ion exchange processes. Different kinds of natural zeolites with high adsorption capacities are frequently used as $\mathrm{NH}_{4}{ }^{+}$exchangers in WRRFs. Calabria et al. (2019) demonstrated the potential of N recovery from an AnMBR permeate with natural zeolite (clinoptilolite) using a regenerating stream of tap water. These authors used tap water regeneration reagent with a flow rate of $60 \mathrm{ml} / \mathrm{min}$ (1.33 bed volumes/min). Guida et al. (2019) studied, on a demonstration scale, the feasibility of $\mathrm{P}$ and $\mathrm{N}$ recovery through an ion exchange process. For this, they used a synthetic zeolite and hybrid anion exchanger (HAIX) for the recovery of $\mathrm{N}$ and $\mathrm{P}$, respectively, 
achieving $90 \% \mathrm{NH}_{4}-\mathrm{N}$ recovery and $95 \% \mathrm{PO}_{4}-\mathrm{P}$ removal. The regenerant solutions were made of $10 \% \mathrm{KCl}$ and $2 \% \mathrm{NaOH}$ to regenerate the synthetic zeolite and the HAIX, respectively.

\subsection{Potentials and limitations}

Different technological solutions have traditionally been applied for nutrient recovery from waste sludge and the different sidestreams associated with sludge handling. However, nutrient recovery strategies should also be applied to the mainstream to maximize nutrient recovery within a biorefinery perspective. For instance, different authors have shown that EBPR systems can obtain maximum mainstream $P$ recovery while meeting the legal effluent requirements (Acevedo et al., 2015; Guisasola et al., 2019). Nonetheless, mainstream EBPR should be combined with other advanced $P$ recovery systems to avoid different problems related to waste sludge management, such as uncontrolled $\mathrm{P}$ precipitation, which increases maintenance costs, and high concentrations of soluble $P$ supernatants returning to the mainstream, which reduces overall $P$ recovery.

Regarding sidestream recovery, large-scale incineration has been tested, reaching high process efficiencies. However, this technology is economically viable only in large WRRFs, mainly because of the high capital expenditure associated with the facilities needed to meet the environmental criteria for WAS incineration (Cieślik and Konieczka, 2017).

In the case of sludge composting, some controversy can be found in the literature regarding the persistence of ARGs and ARB after the composting process. By way of example, Riber et al. (2014) found that the amount of ARGs and ARB decreased in the sludge after composting. However, other studies have shown that sludge composting would be enriched in ARGs (Youngquist et al., 2016). These opposing results suggest that further research is needed to optimize the sludge composting operating parameters to reduce $A R G$ and $A R B$ accumulation and guarantee safe land applications.

$\mathrm{NH}_{3}$ stripping and absorption have been widely tested and full-scale applications worldwide are now in operation. According to Vaneeckhaute et al. (2017) the capital costs of this process are lower than $\mathrm{NH}_{4}{ }^{+}$ removal via biological activated sludge systems, but depend significantly on the technique used to increase the $\mathrm{pH}$. As operating costs vary greatly with operating conditions ( $\mathrm{pH}$, temperature, flow rate), 
future research should focus on reducing scaling and fouling problems, testing citric acid as a scrubbing agent on a larger scale and testing the obtained biofertilizer on farmland with safe land application perspectives.

Potential NRP conversion technologies include thermal, biological, chemical and physical methods. To identify the most effective NRP conversion processes as well as the most suitable for a given application, a thorough comparison of different NRP conversion techniques is absolutely necessary, considering the environmental impact, economic feasibility and technological efficiency. These data will have to be obtained in future investigations.

The sulfur cycle-associated processes combined with enhanced biological phosphorous recovery represent an interesting option for treating wastewaters with high sulfur concentrations. However, the precise $\mathrm{P}$ recovery mechanism and the organisms able to perform this process are still unclear, requiring further research. Also in this line, the promising lab-scale results obtained when coupling anammox and hydroxyapatite precipitation processes require further testing on a larger scale to obtain more information to facilitate full-scale application and evaluate their economic feasibility and efficiency.

Regarding ion exchange processes, the new abundant adsorbent biomaterials that are being explored present attractive advantages such as low cost, simple operation, high efficiency, and absence of sludge formation. However, the presence of competing anions in the liquid to be treated reduce their potential application. Further pilot-scale studies could address different challenges for full-scale implementation, such as reversible fouling of the adsorbent, irrecoverable fouling of the adsorbent (i.e. capacity reduction after several adsorption regeneration cycles) and cost-benefit analyses.

\section{General remarks and future perspectives}

Nutrient recovery from wastewaters provides several benefits: meeting the effluent nutrients levels required by legislation, reducing eutrophication problems and providing a potential fertilizer of agricultural and economic value, reducing the dependence on inorganic fertilizers derived from phosphate rock (Melia et al., 2017).

Traditionally, direct agricultural application of wastewater sludge was the simplest method for nutrient 
recycling. However, as commented before, this method has been limited or even banned in many European countries due to several environmental risks. Thus, nutrient recovery technologies guaranteeing the safety of the obtained product are required. It is necessary to clarify different aspects, such as the fate and environmental impact of priority and emerging substances and persistent organic pollutants, including ARGs and ARB. In this respect, an extensive agronomical validation of the obtained marketable products from wastewater is required.

The overview of nutrient recovery processes within the CE perspective reveals the existence of a notable potential for nutrient recycle. However, there is no single optimal technological solution for all the situations. As Table 3 shows, some technologies are specifically targeted to treat nutrients concentrated streams whereas others can be applied to diluted streams because of their relatively low specific cost per $\mathrm{m}^{3}$. Recovered materials quality as well as treatment costs are usually affected by the type and characteristics of wastewater depending on the selected technology and the obtained product. Some technologies allow nutrient recovering as slow-release fertilizers with negligible heavy metal contents (i.e. crystallization, electrodialysis) or even as pure substances (ammonia stripping, bioelectrochemical systems) whereas others cannot separate toxic materials (i.e. photosynthetic bacteria, microalgae). Regarding the treatment/recovering costs of the different technologies, few information can be found in literature and it is not comparable since many of these technologies are still at lab scale development or they are not optimized to nutrient recovery from same type of streams. An integral approach is required for each case study, taking into account not only the technical feasibility of the solution but also the legal requirements and the local agricultural and industrial demands that affect the total cost. Moreover, as previously commented, governments could incentivate the nutrient recovery products market by means of legislation when economic reasons are weak, including environmental targets in production chains, while implementing nutrient recovery systems also has indirect benefits. For instance, the overall performance of the facility is enhanced, e.g. by avoiding maintenance costs due to the reduction in uncontrolled precipitation or in nutrient back flow with supernatants. Other environmental benefits can also be achieved, e.g. prevention of eutrophication in aquatic environments, reducing the environmental impact of 
phosphate mining, or reducing the energy demand for chemical fertilizer production. The benefits of nutrient recovery technologies should thus be considered, not only for economic targets but also taking into account social and environmental aspects. Life cycle assessment could be a useful tool to study specific advantages or drawbacks as well as the potential environmental impact of nutrient recovery.

New technologies aimed at increasing nutrient recovery from wastewater also require new modeling approaches (Seco et al., 2019, submitted). Different models can be used to fit the type of recovery process (P crystallization, $\mathrm{NH}_{3}$ stripping, etc.), helping to assess nutrient recovery from a new global perspective, including the evaluation of different wastewater management systems. For instance, modeling alternative scenarios based on source separation or decentralized systems are being developed and will require new methods of assessing the benefits of these new decentralized facilities. Recent studies have shown that it is more beneficial to recover fertilizers and energy from undiluted streams (Ishii and Boyer, 2015), while mixing food waste with sewage will increase the possibilities of energy production in centralized and decentralized WRRFs (Pretel et al., 2016).

Global modeling approaches together with multi-objective optimization techniques will be needed to evaluate all the possible scenarios. These integrated models should not only describe the treatment and recovery processes, but also assess the life cycle, product quality and techno-economical aspects as important additional criteria associated with resource recovery. This combination would help decision making when selecting the best plant design and operating conditions, taking different objectives into account (e.g. operating costs, environmental impact, etc.) of different technological solutions for resource recovery. For instance, Solon et al. (2019) evaluated the integration of recovery techniques from wastewater, evaluating the effects of the recovery process on the overall plant performance and providing a basis for the conceptual design of new plant layouts for WRRFs (Fernández-Arévalo et al., 2017; Lizarralde et al., 2019; Martí et al., 2017). In these new approaches, the system boundary definition and evaluation of uncertainties are key aspects when considering future process optimization (Solon et al., 2019). 


\section{Conclusions}

There is great room for improvement of the design, operation and optimization of new technological solutions for nutrient recycling, which would optimize system performance and widen their applicability. Nutrient recovery potential varies greatly and depends on the nature of the matrix to be treated. A better understanding of the key interactions between biological, chemical and physical processes would favor the competitiveness of different hybrid systems. However, although the recovered nutrients may enhance the economics of these processes, government policies and regulations should also look after the environment when there are insufficient economic incentives or social awareness for nutrient recovery.

\section{REFERENCES}

Acevedo, B., Camiña, C., Corona, J.E., Borrás, L., Barat, R., 2015. The metabolic versatility of PAOs as an opportunity to obtain a highly P-enriched stream for further P-recovery. Chem. Eng. J. 270, 459-467.

Acién Fernández, F.G., Gómez-Serrano, C., Fernández-Sevilla, J.M., 2018. Recovery of Nutrients From Wastewaters Using Microalgae. Front. Sustain. Food Syst. 2, 1-13. https://doi.org/10.3389/fsufs.2018.00059

Agrahari, G.K., Shukla, S.K., Verma, N., Bhattacharya, P.K., 2012. Model prediction and experimental studies on the removal of dissolved $\mathrm{NH} 3$ from water applying hollow fiber membrane contactor. J. Memb. Sci.

Aguado, D., Barat, R., Bouzas, A., Seco, A., Ferrer, J., 2019. P-recovery in a pilot-scale struvite crystallisation reactor for source separated urine systems using seawater and magnesium chloride as magnesium sources. Sci. Total Environ. 672, 88-96. https://doi.org/10.1016/J.SCITOTENV.2019.03.485

Alkarawi, M.A.S., Caldwell, G.S., Lee, J.G.M., 2018. Continuous harvesting of microalgae biomass using foam flotation. Algal Res. https://doi.org/10.1016/j.algal.2018.10.018

Amarasiri, M., Kitajima, M., Nguyen, T.H., Okabe, S., Sano, D., 2017. Bacteriophage removal efficiency as a validation and operational monitoring tool for virus reduction in wastewater reclamation: Review. Water Res. 121, 258-269. https://doi.org/10.1016/J.WATRES.2017.05.035

Anjum, M., Al-Makishah, N.H., Barakat, M.A., 2016. Wastewater sludge stabilization using pre-treatment methods. Process Saf. Environ. Prot. https://doi.org/10.1016/j.psep.2016.05.022

Arbib, Z., de Godos, I., Ruiz, J., Perales, J.A., 2017. Optimization of pilot high rate algal ponds for simultaneous nutrient removal and lipids production. Sci. Total Environ. https://doi.org/10.1016/j.scitotenv.2017.02.206

Arias, D.M., Uggetti, E., García-Galán, M.J., García, J., 2017. Cultivation and selection of cyanobacteria in a closed photobioreactor used for secondary effluent and digestate treatment. Sci. Total Environ. 
Awad, A.M., Jalab, R., Minier-Matar, J., Adham, S., Nasser, M.S., Judd, S.J., 2019. The status of forward osmosis technology implementation. Desalination 461, 10-21. https://doi.org/10.1016/J.DESAL.2019.03.013

Bao, J., Wang, X., Gu, J., Dai, X., Zhang, K., Wang, Q., Ma, J., Peng, H., 2020. Effects of macroporous adsorption resin on antibiotic resistance genes and the bacterial community during composting. Bioresour. Technol. 295.

Barat, R., Bouzas, A., Martí, N., Ferrer, J., Seco, A., 2009. Precipitation assessment in wastewater treatment plants operated for biological nutrient removal: A case study in Murcia, Spain. J. Environ. Manage. 90, 850-857.

Blatter, M., Vermeille, M., Furrer, C., Pouget, G., Fischer, F., 2019. Mechanisms and Model Process Parameters in Bioelectrochemical Wet Phosphate Recovery from Iron Phosphate Sewage Sludge. ACS Sustain. Chem. Eng.

Bousek, J., Scroccaro, D., Sima, J., Weissenbacher, N., Fuchs, W., 2016. Influence of the gas composition on the efficiency of ammonia stripping of biogas digestate. Bioresour. Technol. 203, 259-266.

Bouzas, A., Martí, N., Grau, S., Barat, R., Mangin, D., Pastor, L., 2019. Implementation of a global P-recovery system in urban wastewater treatment plants. J. Clean. Prod. https://doi.org/10.1016/j.jclepro.2019.04.126

Calabria, J.L., Lens, P.N.L., Yeh, D.H., 2019. Zeolite Ion Exchange to Facilitate Anaerobic Membrane Bioreactor Wastewater Nitrogen Recovery and Reuse for Lettuce Fertigation in Vertical Hydroponic Systems. Environ. Eng. Sci. 36, 690-698. https://doi.org/10.1089/ees.2018.0439

Campos, J.C., Moura, D., Costa, A.P., Yokoyama, L., Araujo, F.V. da F., Cammarota, M.C., Cardillo, L., 2013.

Evaluation of $\mathrm{pH}$, alkalinity and temperature during air stripping process for ammonia removal from landfill leachate. J. Environ. Sci. Heal. Part A 48, 1105-1113. https://doi.org/10.1080/10934529.2013.774658

Chen, X., Zhou, H., Zuo, K., Zhou, Y., Wang, Q., Sun, D., Gao, Y., Liang, P., Zhang, X., Ren, Z.J., Huang, X., 2017. Self-sustaining advanced wastewater purification and simultaneous in situ nutrient recovery in a novel bioelectrochemical system. Chem. Eng. J. https://doi.org/10.1016/j.cej.2017.07.130

Chen, Y., Yang, A., Meng, F., Zhang, G., 2019. Additives for photosynthetic bacteria wastewater treatment: Latest developments and future prospects. Bioresour. Technol. Reports. https://doi.org/10.1016/j.biteb.2019.100229

Cichy, B., Kużdżał, E., Krztoń, H., 2019. Phosphorus recovery from acidic wastewater by hydroxyapatite precipitation. J. Environ. Manage. 232, 421-427. https://doi.org/10.1016/j.jenvman.2018.11.072

Cieślik, B., Konieczka, P., 2017. A review of phosphorus recovery methods at various steps of wastewater treatment and sewage sludge management. The concept of "no solid waste generation" and analytical methods. J. Clean. Prod. 142, 1728-1740. https://doi.org/10.1016/J.JCLEPRO.2016.11.116

Cordell, D., White, S., 2013. Sustainable Phosphorus Measures: Strategies and Technologies for Achieving Phosphorus Security. Agronomy 3, 86-116. https://doi.org/10.3390/agronomy3010086 
Couto, N., Guedes, P., Ferreira, A.R., Teixeira, M.R., Mateus, E.P., Ribeiro, A.B., 2015. ELECTRODIALYTIC PROCESS of NANOFILTRATION CONCENTRATES - PHOSPHORUS RECOVERY and MICROCYSTINS REMOVAL. Electrochim. Acta 181, 200-207. https://doi.org/10.1016/j.electacta.2015.04.081

Cullen, N., Baur, R., Schauer, P., 2013. Three years of operation of North America's first nutrient recovery facility. Water Sci. Technol. https://doi.org/10.2166/wst.2013.260

Daguerre-Martini, S., Vanotti, M.B., Rodriguez-Pastor, M., Rosal, A., Moral, R., 2018. Nitrogen recovery from wastewater using gas-permeable membranes: Impact of inorganic carbon content and natural organic matter. Water Res. https://doi.org/10.1016/j.watres.2018.03.013

Dai, J., Tang, W.-T., Zheng, Y.-S., Mackey, H.R., Chui, H.K., van Loosdrecht, M.C.M., Chen, G.-H., 2014. An exploratory study on seawater-catalysed urine phosphorus recovery (SUPR). Water Res. 66, 75-84.

Darestani, M., Haigh, V., Couperthwaite, S.J., Millar, G.J., Nghiem, L.D., 2017. Hollow fibre membrane contactors for ammonia recovery: Current status and future developments. J. Environ. Chem. Eng. 5, 1349-1359.

Delgadillo-Velasco, L., Hernández-Montoya, V., Montes-Morán, M.A., Gómez, R.T., Cervantes, F.J., 2020. Recovery of different types of hydroxyapatite by precipitation of phosphates of wastewater from anodizing industry. J. Clean. Prod. 242, 118564. https://doi.org/10.1016/J.JCLEPRO.2019.118564

Díaz, I., Barrón, V., del Campillo, M.C., Torrent, J., 2010. Testing the ability of vivianite to prevent iron deficiency in pot-grown grapevine. Sci. Hortic. (Amsterdam). 123, 464-468. https://doi.org/10.1016/J.SCIENTA.2009.11.006

Dobbs, R., Oppenheim, J., Thompson, F., Brinkman, M., Zornes, M., 2011. Resource Revolution : Meeting the world ' s energy, materials, food, and water needs.

Egle, L., Rechberger, H., Krampe, J., Zessner, M., 2016. Phosphorus recovery from municipal wastewater: An integrated comparative technological, environmental and economic assessment of $\mathrm{P}$ recovery technologies. Sci. Total Environ. 571, 522-542. https://doi.org/10.1016/j.scitotenv.2016.07.019

Egle, L., Rechberger, H., Zessner, M., 2015. Overview and description of technologies for recovering phosphorus from municipal wastewater. Resour. Conserv. Recycl. 105, 325-346. https://doi.org/10.1016/J.RESCONREC.2015.09.016

Fasaei, F., Bitter, J.H., Slegers, P.M., van Boxtel, A.J.B., 2018. Techno-economic evaluation of microalgae harvesting and dewatering systems. Algal Res. https://doi.org/10.1016/j.algal.2017.11.038

Fernández-Arévalo, T., Lizarralde, I., Fdz-Polanco, F., Pérez-Elvira, S.I., Garrido, J.M., Puig, S., Poch, M., Grau, P., Ayesa, E., 2017. Quantitative assessment of energy and resource recovery in wastewater treatment plants based on plant-wide simulations. Water Res. 118, 272-288. https://doi.org/10.1016/j.watres.2017.04.001

Fijalkowski, K., Rorat, A., Grobelak, A., Kacprzak, M.J., 2017. The presence of contaminations in sewage sludge The current situation. J. Environ. Manage. 203, 1126-1136. https://doi.org/10.1016/j.jenvman.2017.05.068 
Fillingham, M., VanderZaag, A.C., Singh, J., Burtt, S., Crolla, A., Kinsley, C., MacDonald, J.D., 2017. Characterizing the performance of gas-permeable membranes as an ammonia recovery strategy from anaerobically digested dairy manure. Membranes (Basel). https://doi.org/10.3390/membranes7040059

Frederichs, T., von Dobeneck, T., Bleil, U., Dekkers, M.J., 2003. Towards the identification of siderite, rhodochrosite, and vivianite in sediments by their low-temperature magnetic properties. Phys. Chem. Earth, Parts A/B/C 28,669679. https://doi.org/10.1016/S1474-7065(03)00121-9

García, D., de Godos, I., Domínguez, C., Turiel, S., Bolado, S., Muñoz, R., 2019. A systematic comparison of the potential of microalgae-bacteria and purple phototrophic bacteria consortia for the treatment of piggery wastewater. Bioresour. Technol. https://doi.org/10.1016/j.biortech.2018.12.095

Garrido-Cardenas, J.A., Manzano-Agugliaro, F., Acien-Fernandez, F.G., Molina-Grima, E., 2018. Microalgae research worldwide. Algal Res. https://doi.org/10.1016/j.algal.2018.08.005

Gherghel, A., Teodosiu, C., De Gisi, S., 2019. A review on wastewater sludge valorisation and its challenges in the context of circular economy. J. Clean. Prod. https://doi.org/10.1016/j.jclepro.2019.04.240

Gonçalves, A.L., Pires, J.C.M., Simões, M., 2017. A review on the use of microalgal consortia for wastewater treatment. Algal Res. https://doi.org/10.1016/j.algal.2016.11.008

González-Camejo, J., Aparicio, S., Ruano, M.V., Borrás, L., Barat, R., Ferrer, J., 2019a. Effect of ambient temperature variations on an indigenous microalgae-nitrifying bacteria culture dominated by Chlorella. Bioresour. Technol. https://doi.org/10.1016/j.biortech.2019.121788

González-Camejo, J., Jiménez-Benítez, A., Ruano, M. V., Robles, A., Barat, R., Ferrer, J., 2019b. Optimising an outdoor membrane photobioreactor for tertiary sewage treatment. J. Environ. Manage.

González, E., Díaz, O., Ruigómez, I., de Vera, C.R., Rodríguez-Gómez, L.E., Rodríguez-Sevilla, J., Vera, L., 2017. Photosynthetic bacteria-based membrane bioreactor as post-treatment of an anaerobic membrane bioreactor effluent. Bioresour. Technol. https://doi.org/10.1016/j.biortech.2017.05.042

Gross, M., Mascarenhas, V., Wen, Z., 2015. Evaluating algal growth performance and water use efficiency of pilotscale revolving algal biofilm (RAB) culture systems. Biotechnol. Bioeng. 112, 2040-2050.

Gu, J., Liu, H., Wang, S., Zhang, M., Liu, Y., 2019. An innovative anaerobic MBR-reverse osmosis-ion exchange process for energy-efficient reclamation of municipal wastewater to NEWater-like product water. J. Clean. Prod. 230, 1287-1293. https://doi.org/10.1016/J.JCLEPRO.2019.05.198

Guida, S., Rubertelli, G., Jefferson, B., Soares, A., 2019. Phosphorus and Ammonia Removal and Recovery through Ion Exchange (IEX) Process at Demonstration Scale, in: IWA (Ed.), 3rd IWA Resource Recovery Conference. Venice, pp. 8-12. 
Guisasola, A., Chan, C., Larriba, O., Lippo, D., Suárez-Ojeda, M.E., Baeza, J.A., 2019. Long-term stability of an enhanced biological phosphorus removal system in a phosphorus recovery scenario. J. Clean. Prod. 214, 308-318.

Guldhe, A., Kumari, S., Ramanna, L., Ramsundar, P., Singh, P., Rawat, I., Bux, F., 2017. Prospects, recent advancements and challenges of different wastewater streams for microalgal cultivation. J. Environ. Manage.

Günther, S., Grunert, M., Müller, S., 2018. Overview of recent advances in phosphorus recovery for fertilizer production. Eng. Life Sci. https://doi.org/10.1002/elsc.201700171

Guo, G., Wu, D., Hao, T., Mackey, H.R., Wei, L., Wang, H., Chen, G., 2016. Functional bacteria and process metabolism of the Denitrifying Sulfur conversion-associated Enhanced Biological Phosphorus Removal (DS-EBPR) system: An investigation by operating the system from deterioration to restoration. Water Res. 95, 289-299.

Harb, M., Hong, P.-Y., 2017. Anaerobic membrane bioreactor effluent reuse: A review of microbial safety concerns N3 - 10.3390/fermentation3030039. Fermentation.

Harb, M., Lou, E., Smith, A.L., Stadler, L.B., 2019. Perspectives on the fate of micropollutants in mainstream anaerobic wastewater treatment. Curr. Opin. Biotechnol. 57, 94-100.

Huang, H., Xiao, D., Zhang, Q., Ding, L., 2014. Removal of ammonia from landfill leachate by struvite precipitation with the use of low-cost phosphate and magnesium sources. J. Environ. Manage. 145, 191-198.

Huang, J., Hankamer, B., Yarnold, J., 2019. Design scenarios of outdoor arrayed cylindrical photobioreactors for microalgae cultivation considering solar radiation and temperature. Algal Res.

Hülsen, T., Barry, E.M., Lu, Y., Puyol, D., Keller, J., Batstone, D.J., 2016. Domestic wastewater treatment with purple phototrophic bacteria using a novel continuous photo anaerobic membrane bioreactor. Water Res.

Hülsen, T., Batstone, D.J., Keller, J., 2014. Phototrophic bacteria for nutrient recovery from domestic wastewater. Water Res. https://doi.org/10.1016/j.watres.2013.10.051

Hülsen, T., Hsieh, K., Lu, Y., Tait, S., Batstone, D.J., 2018. Simultaneous treatment and single cell protein production from agri-industrial wastewaters using purple phototrophic bacteria or microalgae - A comparison. Bioresour. Technol. https://doi.org/10.1016/j.biortech.2018.01.032

Huong, P.T., Jitae, K., Giang, B.L., Nguyen, T.D., Thang, P.Q., 2019. Novel lanthanum-modified activated carbon derived from pine cone biomass as ecofriendly bio-sorbent for removal of phosphate and nitrate in wastewater. Rend. Lincei. Sci. Fis. e Nat. 30, 637-647. https://doi.org/10.1007/s12210-019-00827-3

Huygens, D., Saveyn, H., Tonini, D., Eder, P., Delgado Sancho, L., 2019. Technical proposals for selected new fertilising materials under the Fertilising Products Regulation (Regulation (EU) 2019/1009).

Ishii, S.K.L., Boyer, T.H., 2015. Life cycle comparison of centralized wastewater treatment and urine source 
separation with struvite precipitation: Focus on urine nutrient management. Water Res. 79, 88-103.

Jacob, P., Phungsai, P., Fukushi, K., Visvanathan, C., 2015. Direct contact membrane distillation for anaerobic effluent treatment. J. Memb. Sci. 475, 330-339. https://doi.org/10.1016/J.MEMSCI.2014.10.021

Jamaludin, Z., Rollings-Scattergood, S., Lutes, K., Vaneeckhaute, C., 2018. Evaluation of sustainable scrubbing agents for ammonia recovery from anaerobic digestate. Bioresour. Technol. 270, 596-602.

Jiménez, A., Ferrer, F.J., Greses, S., Ruiz-Martínez, A., Fatone, F., Eusebi, A.L., Mondéjar, N., Ferrer, J., Seco, A., 2019. Reclaimed water for fertigation: sustainability assessment in two Mediterranean case studies within the European Innovation Deal. J. Clean. Prod.

Johansson, S., Ruscalleda, M., Colprim, J., 2017. Phosphorus recovery through biologically induced precipitation by partial nitritation-anammox granular biomass. Chem. Eng. J. 327, 881-888.

Judd, S., van den Broeke, L.J.P., Shurair, M., Kuti, Y., Znad, H., 2015. Algal remediation of CO2 and nutrient discharges: A review. Water Res. https://doi.org/10.1016/j.watres.2015.08.021

Kim, J.E., Kuntz, J., Jang, A., Kim, I.S., Choi, J.Y., Phuntsho, S., Shon, H.K., 2019. Techno-economic assessment of fertiliser drawn forward osmosis process for greenwall plants from urban wastewater. Process Saf. Environ. Prot. 127, 180-188. https://doi.org/10.1016/J.PSEP.2019.05.014

Lahav, O., Telzhensky, M., Zewuhn, A., Gendel, Y., Gerth, J., Calmano, W., Birnhack, L., 2013. Struvite recovery from municipal-wastewater sludge centrifuge supernatant using seawater NF concentrate as a cheap Mg(II) source. Sep.

Purif. Technol. 108, 103-110. https://doi.org/10.1016/J.SEPPUR.2013.02.002

Lateef, S.K., Soh, B.Z., Kimura, K., 2013. Direct membrane filtration of municipal wastewater with chemically enhanced backwash for recovery of organic matter. Bioresour. Technol. 150, 149-155.

Lazarova, V., Choo, K.-H., Cornel, P., 2012. Water-Energy Interactions in Water Reuse. https://doi.org/10.2166/9781780400662

Le Corre, K.S., Valsami-Jones, E., Hobbs, P., Parsons, S.A., 2009. Phosphorus recovery from wastewater by struvite crystallization: A review. Crit. Rev. Environ. Sci. Technol. https://doi.org/10.1080/10643380701640573

Li, B., Boiarkina, I., Yu, W., Huang, H.M., Munir, T., Wang, G.Q., Young, B.R., 2019a. Phosphorous recovery through struvite crystallization: Challenges for future design. Sci. Total Environ. 648, 1244-1256.

Li, B., Udugama, I.A., Mansouri, S.S., Yu, W., Baroutian, S., Gernaey, K. V., Young, B.R., 2019b. An exploration of barriers for commercializing phosphorus recovery technologies. J. Clean. Prod. 229, 1342-1354.

Li, K., Liu, Q., Fang, F., Luo, R., Lu, Q., Zhou, W., Huo, S., Cheng, P., Liu, J., Addy, M., Chen, P., Chen, D., Ruan, R., 2019. Microalgae-based wastewater treatment for nutrients recovery: A review. Bioresour. Technol. 
Lin, L., Zhang, Y., Beckman, M., Cao, W., Ouyang, T., Wang, S., Li, Y.-Y., 2019. Process optimization of anammoxdriven hydroxyapatite crystallization for simultaneous nitrogen removal and phosphorus recovery. Bioresour. Technol. 290, 121779. https://doi.org/10.1016/j.biortech.2019.121779

Lizarralde, I., Fernández-Arévalo, T., Manas, A., Ayesa, E., Grau, P., 2019. Model-based opti mization of phosphorus management strategies in Sur WWTP, Madrid. Water Res. 153, 39-52.

Lu, H., Wang, J., Wang, T., Wang, N., Bao, Y., Hao, H., 2017. Crystallization techniques in wastewater treatment: An overview of applications. Chemosphere. https://doi.org/10.1016/j.chemosphere.2017.01.070

Lu, H., Zhang, G., Zheng, Z., Meng, F., Du, T., He, S., 2019. Bio-conversion of photosynthetic bacteria from non-toxic wastewater to realize wastewater treatment and bioresource recovery: A review. Bioresour. Technol.

Lu, S., Li, H., Tan, G., Wen, F., Flynn, M.T., Zhu, X., 2019. Resource recovery microbial fuel cells for urine-containing wastewater treatment without external energy consumption. Chem. Eng. J.

Lutchmiah, K., Verliefde, A.R.D., Roest, K., Rietveld, L.C., Cornelissen, E.R., 2014. Forward osmosis for application in wastewater treatment: A review. Water Res. 58, 179-197.

Lyu, T., He, K., Dong, R., Wu, S., 2018. The intensified constructed wetlands are promising for treatment of ammonia stripped effluent: Nitrogen transformations and removal pathways. Environ. Pollut. 236, 273-282.

Ma, H., Zhang, Y., Xue, Y., Li, Y.-Y., 2018. A new process for simultaneous nitrogen removal and phosphorus recovery using an anammox expanded bed reactor. Bioresour. Technol. 267, 201-208.

Ma, J., Wang, Z., Xu, Y., Wang, Q., Wu, Z., Grasmick, A., 2013. Organic matter recovery from municipal wastewater by using dynamic membrane separation process. Chem. Eng. J. 219, 190-199.

MacArthur, E., 2013. Towards the circular economy: Economic and business rationale for an accelerated transition. Mai, D.T., Kunacheva, C., Stuckey, D.C., 2018. Post-treatment of anaerobic membrane bioreactor (AnMBR) effluent using activated carbon. Bioresour. Technol. 266, 75-81. https://doi.org/10.1016/J.BIORTECH.2018.06.063

Mailler, R., Gasperi, J., Chebbo, G., Rocher, V., 2014. Priority and emerging pollutants in sewage sludge and fate during sludge treatment. Waste Manag. 34, 1217-26. https://doi.org/10.1016/j.wasman.2014.03.028

Marazzi, F., Bellucci, M., Rossi, S., Fornaroli, R., Ficara, E., Mezzanotte, V., 2019. Outdoor pilot trial integrating a sidestream microalgae process for the treatment of centrate under non optimal climate conditions. Algal Res.

Martí, N., Barat, R., Seco, A., Pastor, L., Bouzas, A., 2017. Sludge management modeling to enhance P-recovery as struvite in wastewater treatment plants. J. Environ. Manage. 196, 340-346.

Marti, N., Bouzas, A., Seco, A., Ferrer, J., 2008. Struvite precipitation assessment in anaerobic digestion processes. Chem. Eng. J. 141, 67-74. https://doi.org/10.1016/J.CEJ.2007.10.023 
Mehta, C.M., Khunjar, W.O., Nguyen, V., Tait, S., Batstone, D.J., 2015. Technologies to Recover Nutrients from Waste Streams: A Critical Review. Crit. Rev. Environ. Sci. Technol. 45, 385-427.

Melia, P.M., Cundy, A.B., Sohi, S.P., Hooda, P.S., Busquets, R., 2017. Trends in the recovery of phosphorus in bioavailable forms from wastewater. Chemosphere 186, 381-395.

Meng, F., Yang, A., Zhang, G., Zhang, P., Ye, J., 2018. Benchmark study of photosynthetic bacteria bio-conversion of wastewater: Carbon source range, fundamental kinetics of substrate degradation and cell proliferation. Bioresour. Technol. Reports. https://doi.org/10.1016/j.biteb.2018.02.003

Mezohegyi, G., Bilad, M.R., Vankelecom, I.F.J., 2012. Direct sewage up-concentration by submerged aerated and vibrated membranes. Bioresour. Technol. 118, 1-7. https://doi.org/10.1016/J.BIORTECH.2012.05.022

Ohlinger, K.N., Young, T.M., Schroeder, E.D., 1998. Predicting struvite formation in digestion. Water Res. 32, 36073614. https://doi.org/10.1016/S0043-1354(98)00123-7

Oliveira, V., Labrincha, J., Dias-Ferreira, C., 2018. Extraction of phosphorus and struvite production from the anaerobically digested organic fraction of municipal solid waste. J. Environ. Chem. Eng. 6, 2837-2845.

Ottosen, L.M., Kirkelund, G.M., Jensen, P.E., 2013. Extracting phosphorous from incinerated sewage sludge ash rich in iron or aluminum. Chemosphere 91, 963-969. https://doi.org/10.1016/j.chemosphere.2013.01.101

Pastor, L., Mangin, D., Ferrer, J., Seco, A., 2010. Struvite formation from the supernatants of an anaerobic digestion pilot plant. Bioresour. Technol. 101, 118-125. https://doi.org/10.1016/J.BIORTECH.2009.08.002

Pedizzi, C., Lema, J.M., Carballa, M., 2018. A combination of ammonia stripping and low temperature thermal pretreatment improves anaerobic post-digestion of the supernatant from organic fraction of municipal solid waste treatment. Waste Manag. 78, 271-278. https://doi.org/10.1016/J.WASMAN.2018.05.051

Peng, L., Dai, H., Wu, Y., Peng, Y., Lu, X., 2018. A comprehensive review of phosphorus recovery from wastewater by crystallization processes. Chemosphere. https://doi.org/10.1016/j.chemosphere.2018.01.098

Pretel, R., Moñino, P., Robles, A., Ruano, M.V., Seco, A., Ferrer, J., 2016. Economic and environmental sustainability of an AnMBR treating urban wastewater and organic fraction of municipal solid waste. J. Environ. Manage. 179, 8392. https://doi.org/10.1016/J.JENVMAN.2016.04.057

Priambodo, R., Shih, Y.J., Huang, Y.H., 2017. Phosphorus recovery as ferrous phosphate (vivianite) from wastewater produced in manufacture of thin film transistor-liquid crystal displays (TFT-LCD) by a fluidized bed crystallizer (FBC). RSC Adv. 7, 40819-40828. https://doi.org/10.1039/c7ra06308c

Puyol, D., Barry, E.M., Hülsen, T., Batstone, D.J., 2017. A mechanistic model for anaerobic phototrophs in domestic wastewater applications: Photo-anaerobic model (PAnM). Water Res. 
Qin, M., Molitor, H., Brazil, B., Novak, J.T., He, Z., 2016. Recovery of nitrogen and water from landfill leachate by a microbial electrolysis cell-forward osmosis system. Bioresour. Technol. 200, 485-492.

Raheem, A., Sikarwar, V.S., He, J., Dastyar, W., Dionysiou, D.D., Wang, W., Zhao, M., 2018. Opportunities and challenges in sustainable treatment and resource reuse of sewage sludge: A review. Chem. Eng. J.

Ravazzini, A.M., van Nieuwenhuijzen, A.F., van der Graaf, J.H.M.J., 2005. Direct ultrafiltration of municipal wastewater: comparison between filtration of raw sewage and primary clarifier effluent. Desalination 178, 51-62.

Recio-Garrido, D., Perrier, M., Tartakovsky, B., 2016. Modeling, optimization and control of bioelectrochemical systems. Chem. Eng. J. 289, 180-190. https://doi.org/10.1016/j.cej.2015.11.112

Riber, L., Poulsen, P.H.B., Al-Soud, W.A., Skov Hansen, L.B., Bergmark, L., Brejnrod, A., Norman, A., Hansen, L.H., Magid, J., Sørensen, S.J., 2014. Exploring the immediate and long-term impact on bacterial communities in soil amended with animal and urban organic waste fertilizers using pyrosequencing and screening for horizontal transfer of antibiotic resistance. FEMS Microbiol. Ecol. 90, 206-24. https://doi.org/10.1111/1574-6941.12403

Richter, L., Wichern, M., Grömping, M., Robecke, U., Haberkamp, J., 2019. Nitrogen Recovery from Process Water of Digested Sludge Dewatering with Membrane Contactors, in: 3rd IWA Resource Recovery Conference. pp. 13-14.

Rittmann, B.E., Mayer, B., Westerhoff, P., Edwards, M., 2011. Capturing the lost phosphorus. Chemosphere 84, 846853. https://doi.org/10.1016/j.chemosphere.2011.02.001

Robles, Á., Ruano, M.V., Charfi, A., Lesage, G., Heran, M., Harmand, J., Seco, A., Steyer, J.-P., Batstone, D.J., Kim, J., Ferrer, J., 2018. A review on anaerobic membrane bioreactors (AnMBRs) focused on modelling and control aspects. Bioresour. Technol. 270, 612-626. https://doi.org/10.1016/J.BIORTECH.2018.09.049

Rockström, J., Steffen, W., Noone, K., Persson, A., Chapin, F.S., Lambin, E.F., Lenton, T.M., Scheffer, M., Folke, C., Schellnhuber, H.J., Nykvist, B., de Wit, C.A., Hughes, T., van der Leuw, S., Rodhe, H., Sörlin, S., Snyder, P.K., Costanza, R., Svedin, U., Falkenmark, M., Karlberg, L., Corell, R.W., Fabry, V.J., Hansen, J., Walker, B., Liverman, D., Richardson, K., Crutzen, P., Foley, J.A., 2009. A safe operating space for humanity. Nature 461.

Romero-Villegas, G.I., Fiamengo, M., Acién-Fernández, F.G., Molina-Grima, E., 2018. Utilization of centrate for the outdoor production of marine microalgae at the pilot-scale in raceway photobioreactors. J. Environ. Manage.

Rotta, E.H., Bitencourt, C.S., Marder, L., Bernardes, A.M., 2019. Phosphorus recovery from low phosphate-containing solution by electrodialysis. J. Memb. Sci. 573, 293-300. https://doi.org/10.1016/j.memsci.2018.12.020

Rubio-Rincón, F.J., Welles, L., Lopez-Vazquez, C.M., Nierychlo, M., Abbas, B., Geleijnse, M., Nielsen, P.H., van Loosdrecht, M.C.M., Brdjanovic, D., 2017. Long-term effects of sulphide on the enhanced biological removal of phosphorus: The symbiotic role of Thiothrix caldifontis. Water Res. 116, 53-64.

Salehi, S., Cheng, K.Y., Heitz, A., Ginige, M.P., 2018. Re-visiting the Phostrip process to recover phosphorus from 
municipal wastewater. Chem. Eng. J. 343, 390-398. https://doi.org/10.1016/J.CEJ.2018.02.074

Sancho, I., Lopez-Palau, S., Arespacochaga, N., Cortina, J.L., 2019. New concepts on carbon redirection in wastewater treatment plants: A review. Sci. Total Environ. 647, 1373-1384.

Santos, F.M., Pires, J.C.M., 2018. Nutrient recovery from wastewaters by microalgae and its potential application as bio-char. Bioresour. Technol. https://doi.org/10.1016/j.biortech.2018.07.119

Seco, A., Aparicio, S., González-Camejo, J., Jiménez-Benítez, A., Mateo, O., Mora, J.F., Noriega-Hevia, G., SanchisPerucho, P., Serna-García, R., Zamorano-López, N., Giménez, J.B., Ruiz-Martínez, A., Aguado, D., Barat, R., Borrás, L., Bouzas, A., Martí, N., Pachés, M., Ribes, J., Robles, A., Ruano, M. V., Serralta, J., Ferrer, J., 2018. Resource recovery from sulphate-rich sewage through an innovative anaerobic-based water resource recovery facility (WRRF). Water Sci. Technol. 78, 1925-1936. https://doi.org/10.2166/wst.2018.492

Seco, A., Ruano, M., Ruiz-Martinez, A., Robles, A., Barat, R., Serralta, J., Ferrer, J., 2019. The key role of plant-wide modelling in wastewater treatment: experiences and Challenges. Water Sci. Technol.

Serna-Maza, A., Heaven, S., Banks, C.J., 2015. Biogas stripping of ammonia from fresh digestate from a food waste digester. Bioresour. Technol. 190, 66-75. https://doi.org/10.1016/j.biortech.2015.04.041

Shi, L., Hu, Y., Xie, S., Wu, G., Hu, Z., Zhan, X., 2018. Recovery of nutrients and volatile fatty acids from pig manure hydrolysate using two-stage bipolar membrane electrodialysis. Chem. Eng. J. 334, 134-142.

Shi, L., Xie, S., Hu, Z., Wu, G., Morrison, L., Croot, P., Hu, H., Zhan, X., 2019. Nutrient recovery from pig manure digestate using electrodialysis reversal: Membrane fouling and feasibility of long-term operation. J. Memb. Sci.

Singh, N., Dhiman, S., Basu, S., Balakrishnan, M., Petrinic, I., Helix-Nielsen, C., 2019. Dewatering of sewage for nutrients and water recovery by Forward Osmosis (FO) using divalent draw solution. J. Water Process Eng. 31, 100853. https://doi.org/10.1016/J.JWPE.2019.100853

Solon, K., Volcke, E.I.P., Spérandio, M., Van Loosdrecht, M.C.M., 2019. Resource recovery and wastewater treatment modelling. Environ. Sci. Water Res. Technol. 5, 631-642. https://doi.org/10.1039/c8ew00765a

Tarayre, C., De Clercq, L., Charlier, R., Michels, E., Meers, E., Camargo-Valero, M., Delvigne, F., 2016. New perspectives for the design of sustainable bioprocesses for phosphorus recovery from waste. Bioresour. Technol. 206, 264-274. https://doi.org/10.1016/J.BIORTECH.2016.01.091

Tarpeh, W.A., Barazesh, J.M., Cath, T.Y., Nelson, K.L., 2018. Electrochemical Stripping to Recover Nitrogen from Source-Separated Urine. Environ. Sci. Technol. 52, 1453-1460. https://doi.org/10.1021/acs.est.7b05488

Thompson Brewster, E., Ward, A.J., Mehta, C.M., Radjenovic, J., Batstone, D.J., 2017. Predicting scale formation during electrodialytic nutrient recovery. Water Res. https://doi.org/10.1016/j.watres.2016.11.063 
Turon, V., Trably, E., Fouilland, E., Steyer, J.P., 2016. Potentialities of dark fermentation effluents as substrates for microalgae growth: A review. Process Biochem. https://doi.org/10.1016/j.procbio.2016.03.018

Uggetti, E., Sialve, B., Hamelin, J., Bonnafous, A., Steyer, J.P., 2018. CO2 addition to increase biomass production and control microalgae species in high rate algal ponds treating wastewater. J. CO2 Util.

Ukwuani, A.T., Tao, W., 2016. Developing a vacuum thermal stripping - acid absorption process for ammonia recovery from anaerobic digester effluent. Water Res. 106, 108-115. https://doi.org/10.1016/j.watres.2016.09.054

Vaneeckhaute, C., Lebuf, V., Michels, E., Belia, E., Vanrolleghem, P.A., Tack, F.M.G., Meers, E., 2017. Nutrient Recovery from Digestate: Systematic Technology Review and Product Classification. Waste and Biomass Valorization 8, 21-40. https://doi.org/10.1007/s12649-016-9642-x

Venkatesan, A.K., Gan, W., Ashani, H., Herckes, P., Westerhoff, P., 2018. Size exclusion chromatography with online ICP-MS enables molecular weight fractionation of dissolved phosphorus species in water samples. Water Res. 133, 264-271. https://doi.org/10.1016/j.watres.2018.01.048

Venkiteshwaran, K., McNamara, P.J., Mayer, B.K., 2018. Meta-analysis of non-reactive phosphorus in water, wastewater, and sludge, and strategies to convert it for enhanced phosphorus removal and recovery. Sci. Total Environ. 644, 661-674. https://doi.org/10.1016/j.scitotenv.2018.06.369

Viruela, A., Robles, Á., Durán, F., Ruano, M.V., Barat, R., Ferrer, J., Seco, A., 2018. Performance of an outdoor membrane photobioreactor for resource recovery from anaerobically treated sewage. J. Clean. Prod. 178, 665-674. https://doi.org/10.1016/j.jclepro.2017.12.223

Vo, H.N.P., Ngo, H.H., Guo, W., Nguyen, T.M.H., Liu, Yiwen, Liu, Yi, Nguyen, D.D., Chang, S.W., 2019. A critical review on designs and applications of microalgae-based photobioreactors for pollutants treatment. Sci. Total Environ. https://doi.org/10.1016/j.scitotenv.2018.09.282

Vogel, C., Exner, R.M., Adam, C., 2013. Heavy metal removal from sewage sludge ash by thermochemical treatment with polyvinylchloride. Environ. Sci. Technol. 47, 563-567. https://doi.org/10.1021/es300610e

Volpin, F., Heo, H., Hasan Johir, M.A., Cho, J., Phuntsho, S., Shon, H.K., 2019. Techno-economic feasibility of recovering phosphorus, nitrogen and water from dilute human urine via forward osmosis. Water Res. 150, 47-55.

Wäeger-Baumann, F., Fuchs, W., 2012. The Application of Membrane Contactors for the Removal of Ammonium from Anaerobic Digester Effluent. Sep. Sci. Technol. https://doi.org/10.1080/01496395.2011.653468

Westley, F., Olsson, P., Folke, C., Homer-Dixon, T., Vredenburg, H., Loorbach, D., Thompson, J., Nilsson, M., Lambin, E., Sendzimir, J., Banerjee, B., Galaz, V., Van Der Leeuw, S., 2011. Tipping toward sustainability: Emerging pathways of transformation. Ambio 40, 762-780. https://doi.org/10.1007/s13280-011-0186-9

Wilfert, P., Dugulan, A.I., Goubitz, K., Korving, L., Witkamp, G.J., Van Loosdrecht, M.C.M., 2018. Vivianite as the main 
phosphate mineral in digested sewage sludge and its role for phosphate recovery. Water Res. 144, 312-321.

Wu, D., Ekama, G.A., Wang, H.G., Wei, L., Lu, H., Chui, H.K., Liu, W.T., Brdjanovic, D., Van Loosdrecht, M.C.M., Chen, G.H., 2014. Simultaneous nitrogen and phosphorus removal in the sulfur cycle-associated Enhanced Biological Phosphorus Removal (EBPR) process. Water Res. 49, 251-264.

Wu, Y., Luo, J., Zhang, Q., Aleem, M., Fang, F., Xue, Z., Cao, J., 2019. Potentials and challenges of phosphorus recovery as vivianite from wastewater: A review. Chemosphere.

Xie, M., Shon, H.K., Gray, S.R., Elimelech, M., 2016. Membrane-based processes for wastewater nutrient recovery: Technology, challenges, and future direction. Water Res. 89, 210-221.

Xu, Q., Chen, Z., Wu, Z., Xu, F., Yang, D., He, Q., Li, G., Chen, Y., 2019. Novel lanthanum doped biochars derived from lignocellulosic wastes for efficient phosphate removal and regeneration. Bioresour. Technol. 289, 121600.

Xu, X., Gu, X., Wang, Zhongyang, Shatner, W., Wang, Zhenjun, 2019. Progress, challenges and solutions of research on photosynthetic carbon sequestration efficiency of microalgae. Renew. Sustain. Energy Rev.

Xue, G., Jiang, M., Chen, H., Sun, M., Liu, Y., Li, X., Gao, P., 2019. Critical review of ARGs reduction behavior in various sludge and sewage treatment processes in wastewater treatment plants. Crit. Rev. Environ. Sci. Technol. 49, 1623-1674. https://doi.org/10.1080/10643389.2019.1579629

Yan, T., Ye, Y., Ma, H., Zhang, Y., Guo, W., Du, B., Wei, Q., Wei, D., Ngo, H.H., 2018. A critical review on membrane hybrid system for nutrient recovery from wastewater. Chem. Eng. J. 348, 143-156.

Yang, E., Chae, K.J., Choi, M.J., He, Z., Kim, I.S., 2019. Critical review of bioelectrochemical systems integrated with membrane-based technologies for desalination, energy self-sufficiency, and high-efficiency water and wastewater treatment. Desalination. https://doi.org/10.1016/j.desal.2018.11.007

Yang, Y., Song, W., Lin, H., Wang, W., Du, L., Xing, W., 2018. Antibiotics and antibiotic resistance genes in global lakes: A review and meta-analysis. Environ. Int. https://doi.org/10.1016/j.envint.2018.04.011

Yetilmezsoy, K., llhan, F., Kocak, E., Akbin, H.M., 2017. Feasibility of struvite recovery process for fertilizer industry: A study of financial and economic analysis. J. Clean. Prod. 152, 88-102.

Youngquist, C.P., Mitchell, S.M., Cogger, C.G., 2016. Fate of Antibiotics and Antibiotic Resistance during Digestion and Composting: A Review. J. Environ. Qual. 45, 537-45. https://doi.org/10.2134/jeq2015.05.0256

Zhang, Y., Desmidt, E., Van Looveren, A., Pinoy, L., Meesschaert, B., Van der Bruggen, B., 2013. Phosphate Separation and Recovery from Wastewater by Novel Electrodialysis. Environ. Sci. Technol. 47, 5888-5895.

Zhou, Q., Zhang, P., Zhang, G., Peng, M., 2015. Biomass and pigments production in photosynthetic bacteria wastewater treatment: Effects of photoperiod. Bioresour. Technol. https://doi.org/10.1016/j.biortech.2015.04.092 
Table 1. Average biomass productivities and nutrient removal efficiencies for different reactor configurations of photosynthetic-based systems. AnMBR: anaerobic membrane bioreactor; HRAP: high-rate algal pond; MBR: membrane bioreactor; MPBR: membrane photobioreactor; $\mathrm{NH}_{4}-\mathrm{N}$ : ammonium; $\mathrm{NO}_{3}-\mathrm{N}$ : nitrate; PBR: photobioreactor; $\mathrm{PO} 4-\mathrm{P}$ : phosphate; PSB:photosynthetic bacteria; TAN: total ammoniacal N; TN: total N; TP: total P

\begin{tabular}{|c|c|c|c|c|c|}
\hline Photosynthetic-based system & Wastewater Type & Technology Type & Biomass productivity & Nutrient removal ratio & References \\
\hline \multirow{4}{*}{ PSB } & Sewage & Photo anaerobic MBR & - & TN, 18.9\%-92.2\% ; TP, 39.0\%-97.5\% & Hülsen et al., 2016 \\
\hline & AnMBR effluent from sewage & MPBR & - & $\mathrm{TN}, 39 \% ; \mathrm{TP} \approx 0 \%$ & González et al., 2017 \\
\hline & Agro-industrial wastewater & Flasks & - & $\mathrm{NH}_{4}-\mathrm{N}, 80 \% ; \mathrm{PO}_{4}-\mathrm{P}, 55 \%$ & Hülsen et al., 2018 \\
\hline & Diluted Piggery wastewater & PBR & $5.4-16.6 \mathrm{~g} \cdot \mathrm{m}^{-2} \cdot \mathrm{d}^{-1}$ & TN, 48\%-83\%;TP 81\%- 89\%; & García et al., 2019 \\
\hline \multirow{3}{*}{ Microalgae-Bacteria } & Diluted Piggery wastewater & PBR & $10.4-18.4 \mathrm{~g} \cdot \mathrm{m}^{-2} \cdot \mathrm{d}^{-1}$ & TN, 47\%-87\%;TP 83\%- 91\%; & García et al., 2019 \\
\hline & Agro-industrial wastewater & Flasks & - & $\mathrm{NH}_{4}-\mathrm{N}, 91 \pm 29 \% ; \mathrm{PO}_{4}-\mathrm{P}, 73 \pm 27 \%$ & Hülsen et al., 2018 \\
\hline & AnMBR effluent from sewage & MPBR & $17.6 \mathrm{~g} \cdot \mathrm{m}^{-2} \cdot \mathrm{d}^{-1}$ & TN, 66\% TP 73\%; & González-Camejo et al., 2019b \\
\hline \multirow{2}{*}{ Microalgae } & Diluted Centrate from sewage & HRAP & $32.42 \mathrm{~g} \cdot \mathrm{m}^{-2} \cdot \mathrm{d}^{-1}$ & TN, 90\% TP, $82 \%$ & Romero-Villegas et al., 2018 \\
\hline & Secondary Effluent & HRAP & $32.42 \mathrm{~g} \cdot \mathrm{m}^{-2} \cdot \mathrm{d}^{-1}$ & TN, $82 \%$ TP, $91 \%$ & Arbib et al., 2017 \\
\hline Microalgae/cyanobacteria & Secondary Effluent & PBR & $0.039 \mathrm{~g} \cdot \mathrm{L}-1 \cdot \mathrm{d}^{-1}$ & TAN, 95\%; $\mathrm{NO}_{3}-\mathrm{N}, 91 \%$ PO4-P, 95\% & Arias et al., 2017 \\
\hline
\end{tabular}


Table 2. Characteristics of the potential flows for $P$ recovery by crystallization

\begin{tabular}{|c|c|c|c|c|c|c|c|c|c|c|c|}
\hline Source & $\begin{array}{c}\text { Source } \\
\text { characteristics }\end{array}$ & $\begin{array}{l}\mathrm{PO}_{4 .} \cdot \mathrm{P} \\
\text { (mg/L) }\end{array}$ & $\begin{array}{l}\mathrm{NH}_{4}-\mathrm{N} \\
(\mathrm{mg} / \mathrm{L})\end{array}$ & Mg source & $\begin{array}{c}\mathrm{pH} \\
\text { adjustment }\end{array}$ & $\begin{array}{c}\text { Reactor } \\
\text { type }\end{array}$ & Scale & Technology & $\begin{array}{c}\text { Recovery } \\
\text { efficiency } \\
(\%)\end{array}$ & Crystal shape and size & Reference \\
\hline \multirow{4}{*}{ Urine } & No-mixa & 196 & 378 & $\mathrm{MgCl}$; seawater & $\mathrm{NaOH}$ & CSTR & Pilot & - & $>87$ & X-Shaped crystals $(>100 \mu \mathrm{m})$ & Aguado et al., 2019 \\
\hline & $\begin{array}{l}\text { No-mixa } \\
\text { Undiluted }\end{array}$ & $\begin{array}{c}88 \pm 37 \\
384 \pm 39\end{array}$ & $\begin{array}{l}5615 \pm 266 \\
1447 \pm 203\end{array}$ & $\mathrm{MgCl} 2 ; \mathrm{MgOH}$ & $\begin{array}{l}\mathrm{NaOH}, \\
\text { aeration }\end{array}$ & CSTR & Pilot & - & 55 & Coffin shaped crystals $(>100 \mu \mathrm{m})$ & Wei et al., 2018 \\
\hline & No-mixa & $217 \pm 19.8$ & $4591 \pm 85.3$ & $\mathrm{MgCl} 2$ & $\mathrm{NaOH}$ & CSTR & Lab & - & $99 b$ & X-Shaped crystals $(91 \mu \mathrm{m})$ & Rotentalp et al., 2010 \\
\hline & Undiluted & $227 \pm 17$ & $3700 \pm 600$ & $\mathrm{MgCl} 2$ & None & FBR & Pilot & - & $85-99$ & Round pellets (0.3 - $6 \mathrm{~mm})$ & Zamora et al., 2016 \\
\hline \multirow{2}{*}{$\begin{array}{l}\text { Thickener } \\
\text { supernatant }\end{array}$} & $\begin{array}{l}\text { Elutriated } \\
\text { sludge }\end{array}$ & $96 \pm 14$ & $102 \pm 9$ & $\mathrm{MgCl} 2$ & $\mathrm{NaOH}$ & CSRT & Pilot & PHORWATER® & 87 & Coarse crystals (>200 $\mu \mathrm{m})$ & Bouzas et al., 2019 \\
\hline & $\begin{array}{l}\text { Elutriated } \\
\text { sludge }\end{array}$ & na & na & $\mathrm{MgCl} 2$ & $\mathrm{NaOH}$ & UFBR & Industrial & $\begin{array}{c}\text { PEARL } ® / \\
\text { WASSTRIP } ® \\
\end{array}$ & 83-90 & Round pellets $(0.9-3 \mathrm{~mm})$ & Cullen et al., 2013 \\
\hline $\begin{array}{c}\text { Industrial } \\
\text { Wastewater }\end{array}$ & UASB efflents & $55-150$ & na & $\mathrm{MgCl} 2$ & $\mathrm{NaOH}$ & CSTR & Industrial & NuReSys ${ }^{\circledR}$ & $72-90^{b}$ & Round pellets (1 - $3 \mathrm{~mm})$ & nuresys.be \\
\hline \multirow{2}{*}{$\begin{array}{l}\text { Anaerobic } \\
\text { sludge }\end{array}$} & \multirow{2}{*}{$\begin{array}{l}\text { Digested } \\
\text { sludge }\end{array}$} & $387-400$ & na & $\mathrm{MgCl} 2$ & Aeration & Airlift & Industrial & AirPrex® & $14-21$ & Coarse crystals $(>200 \mu \mathrm{m})$ & Zhou et al., 2019 \\
\hline & & 220 & na & $\mathrm{MgCl} 2$ & Aeration & CSTR & Industrial & NuReSys $®$ & $86^{b}$ & Round pellets (1 - $3 \mathrm{~mm})$ & nuresys.be \\
\hline \multirow{5}{*}{$\begin{array}{l}\text { Digester } \\
\text { supernatant }\end{array}$} & \multirow{5}{*}{$\begin{array}{l}\text { Dewatering } \\
\text { centrate }\end{array}$} & na & na & $\mathrm{MgCl} 2$ & $\mathrm{NaOH}$ & UFBR & Industrial & PEARL® & $83-90$ & Round pellets $(0.9-3 \mathrm{~mm})$ & Egle et al., 2015; Li et al., 2019 \\
\hline & & $200-260$ & $2100-3600$ & $\mathrm{MgCl} 2$ & $\mathrm{NaOH}$ & CSRT & Pilot & STRUVIA ${ }^{\text {TM }}$ & $80-95$ & Coarse crystals $(100-500 \mu \mathrm{m})$ & cordis.europa.eu/project/rcn/105528 \\
\hline & & na & na & $\mathrm{MgCl} 2$ & $\begin{array}{l}\mathrm{NaOH}, \\
\text { aeration }\end{array}$ & UFBR & Industrial & $\begin{array}{c}\text { DHV } \\
\text { Crystalactor }\end{array}$ & 70 & na & van Houwelingen et al., 2018 \\
\hline & & $60-407$ & $150-800$ & $\mathrm{MgO}$ & Aeration & CSRT & Industrial & PHOSPAQ ${ }^{\text {TM }}$ & $75-95$ & Coffin shaped crystals ( $\sim 0.7 \mathrm{~mm})$ & Abma et al, 2010; Hendrickx et al., 2015 \\
\hline & & 450 & na & $\mathrm{MgCl} 2$ & $\mathrm{NaOH}$ & CSTR & Industrial & NuReSys $®$ & $95^{b}$ & Round pellets (1-3 mm) & nuresys.be \\
\hline
\end{tabular}


Table 3. Comparative analysis of different technologies

\begin{tabular}{|c|c|c|c|c|c|c|c|}
\hline Technology & Wastewater type & Recovered product & Products' properties & Main applications & Potentials & Limitations & Cost $\left(^{*}\right)$ \\
\hline Crystallization & $\begin{array}{c}\text { Urine } \\
\text { Thickener supernatant } \\
\text { Industrial wastewater } \\
\text { Anaerobic sludge } \\
\text { Digester supernatant }\end{array}$ & $\begin{array}{c}\text { Struvite } \\
\left(\mathrm{MgNH}_{4} \mathrm{PO}_{4} \cdot 6 \mathrm{H}_{2} \mathrm{O}\right)\end{array}$ & $\begin{array}{l}\text { X-Shaped crystals } \\
\text { Coffin shaped crystals } \\
\text { Round pellets } \\
\text { Coarse crystals }\end{array}$ & $\begin{array}{c}\text { Fertilizer } \\
\text { Precursor for fertilizer } \\
\text { manufacturing } \\
\text { Raw material for } \\
\text { chemical industry }\end{array}$ & $\begin{array}{c}\text { Notable recovery rates } \\
\text { Marketable product (100-500 euros/ton) } \\
\text { Limited environmental impact } \\
\text { Reduction of uncontrolled P precipitation } \\
\text { Reduction of polyelectrolyte needs and } \\
\text { dewatered sludge disposal in WWTPs }\end{array}$ & $\begin{array}{l}\text { Product quality/fertilizing properties } \\
\text { Economic feasibility } \\
\text { Legal framework } \\
\text { Social acceptance } \\
\text { P recovery strategies needed }\end{array}$ & $\begin{array}{l}\text { (1) } 6-10 \text { Euro } \cdot \mathrm{kg}^{-1} \mathrm{P} \\
\text { recovered }\end{array}$ \\
\hline Crystallization & $\begin{array}{l}\text { Thickener supernatant } \\
\text { Digester supernatant } \\
\text { Raw sewage }\end{array}$ & $\begin{array}{c}\text { Vivianite } \\
\mathrm{Fe}_{3}\left(\mathrm{PO}_{4}\right)_{2} \cdot 8 \mathrm{H}_{2} \mathrm{O}\end{array}$ & $\begin{array}{c}\text { White-Blue crystals } \\
\text { Monoclinic prism } \\
\text { Particles between 20- } \\
150 \mu \mathrm{m}\end{array}$ & $\begin{array}{c}\text { Fertilizer } \\
\text { Production of } \mathrm{LiFePO}_{4}\end{array}$ & $\begin{array}{l}\text { Slow-release fertilizer } \\
\text { Can mitigate chlorosis from iron deficiency } \\
\text { Marketable product (10 euros } / \mathrm{kg} \text { ) }\end{array}$ & $\begin{array}{c}\text { Difficult to separate from sludge } \\
\text { Difficult to remove impurities }(\mathrm{Mg}, \mathrm{Ca} \text { ) and } \\
\text { organic matter } \\
\text { Instable product if not pure }\end{array}$ & n.a. \\
\hline Microalgae & $\begin{array}{l}\text { Secondary effluent } \\
\text { Primary settler effluent } \\
\text { AnMBR effluent } \\
\text { Digester supernatants } \\
\text { Manure }\end{array}$ & $\begin{array}{l}\text { Microalgae-based bio- } \\
\text { fertilizer after harvesting } \\
\text { and composting or } \\
\text { thermochemical processes } \\
\text { (biochar) }\end{array}$ & $\begin{array}{l}\text { Organic fertilizer } \\
\text { Rich in trace elements } \\
\text { and natural } \\
\text { phytohormones which } \\
\text { improves crops quality }\end{array}$ & Biofertilizer & $\begin{array}{c}\text { Improves soil properties } \\
\text { Reduce nutrient losses through a } \\
\text { consistent release of nutrients } \\
\text { Small carbon footprint ( } \mathrm{C} \text { sequestration) } \\
\text { Competitive yields } \\
\text { Up to } 90 \% \text { of nutrient content in WW }\end{array}$ & $\begin{array}{l}\text { Further treatment needed for biofertilizer } \\
\text { Low degradability of the cell wall } \\
\text { Depends on solar radiation availability } \\
\text { Extensive surfaces are required } \\
\text { Harvesting phase still challenging }\end{array}$ & (1) $0.1-2$ Euro $\cdot \mathrm{kg}^{-1}$ \\
\hline $\begin{array}{l}\text { Photosynthetic } \\
\text { Bacteria }\end{array}$ & $\begin{array}{l}\text { Non-toxic industrial wastewaters } \\
\text { Domestic wastewater }\end{array}$ & $\begin{array}{l}\text { PSB-based biofertilizer } \\
\text { after harvesting }\end{array}$ & $\begin{array}{c}\text { Organic fertilizer } \\
\text { Rich in carotenoids, } \\
\text { coenzyme } Q, \text { vitamin } B \text {, } \\
\text { protein... }\end{array}$ & Biofertilizer & $\begin{array}{c}\text { High yield of hydrogen } \\
\text { High tolerance over disturbances } \\
\text { Assimilates } \mathrm{C}, \mathrm{N} \text { and } \mathrm{P} \text { in a single stage } \\
\text { Content of many high-value substances } \\
\text { Reduced sludge production }\end{array}$ & $\begin{array}{c}\text { Further treatment needed for biofertilizer } \\
\text { Poor settling properties } \\
\text { Depends on infrared light availability } \\
\text { Still at lab scale } \\
\text { Further safety criteria needed }\end{array}$ & n.a. \\
\hline Ammonia stripping & $\begin{array}{l}\text { High ammonia concentration } \\
\left(\mathrm{NH}_{4}-\mathrm{N}\right)>2000 \mathrm{mg} / \mathrm{L} \text { streams } \\
\mathrm{N} \text {-rich digestate and manure }\end{array}$ & $\begin{array}{l}\text { Ammonium sulfate } \\
\text { (alternatively, ammonium } \\
\text { nitrate or ammonium } \\
\text { citrate, depending on the } \\
\text { scrubbing agent used) } \\
\end{array}$ & $\begin{array}{l}\text { Fertilizer rich in direct } \\
\text { available macro-nutrients } \\
\qquad(\mathrm{N}, \mathrm{S})\end{array}$ & Agriculture & $\begin{array}{l}\text { High } \mathrm{N} \text { removal efficiencies (up to } 98 \% \text { ) } \\
\text { Odor removal } \\
\text { Attractive biofertilizer for regions with } \mathrm{N} \\
\text { demand }\end{array}$ & $\begin{array}{l}\text { High operating costs } \\
\text { High alkalinity and pH of the effluent } \\
\text { Scaling and fouling problems }\end{array}$ & $\begin{array}{l}\text { (2) High } \\
\text { (3) Med }\end{array}$ \\
\hline $\begin{array}{l}\text { Membrane } \\
\text { contactors }\end{array}$ & $\begin{array}{l}\text { Nitrogen-rich solutions (i.e. } \\
\text { centrate streams, industrial } \\
\text { wastewaters }\end{array}$ & Ammonium sulfate & $\begin{array}{l}\text { Appropriate for crops } \\
\text { such as corn or wheat, } \\
\text { pre-seeding fertilizer }\end{array}$ & Fertilizer & $\begin{array}{c}\text { High } \mathrm{N} \text { removal efficiencies (> to } 99 \% \text { ) } \\
\text { Reduce nitrogen load and aeration energy } \\
\text { consumption. }\end{array}$ & $\begin{array}{l}\text { Membrane fouling needs further research } \\
\text { prior to develop full scale applications }\end{array}$ & $\begin{array}{l}\text { (1) } 3 \$ \cdot \mathrm{kg}^{-1} \mathrm{~N} \\
\text { recovered }\end{array}$ \\
\hline Electrodialysis & $\begin{array}{l}\text { Diluted streams (urban } \\
\text { wastewater) } \\
\text { Concentrated streams (pig } \\
\text { manure, centrate, urine) }\end{array}$ & $\begin{array}{l}\text { Solution with high } \mathrm{N} \text { and/or } \\
\mathrm{P} \text { concentrations to } \\
\text { produce ammonium sulfate } \\
\text { and struvite }\end{array}$ & $\begin{array}{l}\text { Struvite: Slow-release } \\
\text { fertilizer with negligible } \\
\text { heavy metal content }\end{array}$ & Fertilizer & $\begin{array}{l}\text { Concentrates } N \text { and } P \text { from dilute streams } \\
\text { such as urban wastewater. } \\
\text { P recovery from sewage sludge ashes }\end{array}$ & Lab scale applications only & (2) $3.5-6.5 \mathrm{kWh} \cdot \mathrm{kg}^{-1} \mathrm{~N}$ \\
\hline $\begin{array}{l}\text { Bioelectrochemical } \\
\text { systems }\end{array}$ & $\begin{array}{c}\text { Diluted streams (urban } \\
\text { wastewater) and ammonium-rich } \\
\text { wastewaters (urine, swine } \\
\text { wastewater, landfill leachate) } \\
\end{array}$ & $\begin{array}{l}\text { Free ammonia gas that can } \\
\text { be absorbed in an acidic } \\
\text { solution }\end{array}$ & $\begin{array}{l}\text { Can be used for } \\
\text { industrial purposes }\end{array}$ & $\begin{array}{l}\text { Chemical industry } \\
\text { Agriculture }\end{array}$ & $\begin{array}{l}\text { High N removal efficiencies }(70-90 \%) \\
\text { Suitable for nitrogen rich streams: reject } \\
\text { water, urine, landfill leachate. }\end{array}$ & Not full scale applications evaluated yet & $\begin{array}{c}\text { (1) Costs }<\text { revenues } \\
\text { for } \mathrm{N} \text { removal from } \\
\text { urine }\end{array}$ \\
\hline $\begin{array}{l}\text { AnMBR } \\
\text { DMF }\end{array}$ & $\begin{array}{l}\text { Diluted streams (urban } \\
\text { wastewater) }\end{array}$ & $\begin{array}{l}\text { Nutrient-rich water with } \\
\text { negligible solids } \\
\text { concentration }\end{array}$ & $\begin{array}{l}\text { Appropriate for } \\
\text { fertirigation }\end{array}$ & $\begin{array}{c}\text { Agriculture } \\
\text { Urban irrigation }\end{array}$ & $\begin{array}{c}\text { Simultaneous energy, water and nutrient } \\
\text { recovery } \\
\text { Enables decentralized anaerobic treatment } \\
\text { of UWW }\end{array}$ & $\begin{array}{l}\text { Not full scale applications evaluated yet } \\
\text { Sensitive areas require nutrient removal } \\
\text { Regulation for nutrient-rich water use in } \\
\text { agriculture }\end{array}$ & $\begin{array}{c}<0.4 \mathrm{kWh}_{\text {per }} \mathrm{m}^{3} \text { of } \\
\text { treated water }(<8 \\
\left.\mathrm{kWh} \cdot \mathrm{kg}^{-1} \mathrm{~N}\right)\end{array}$ \\
\hline
\end{tabular}




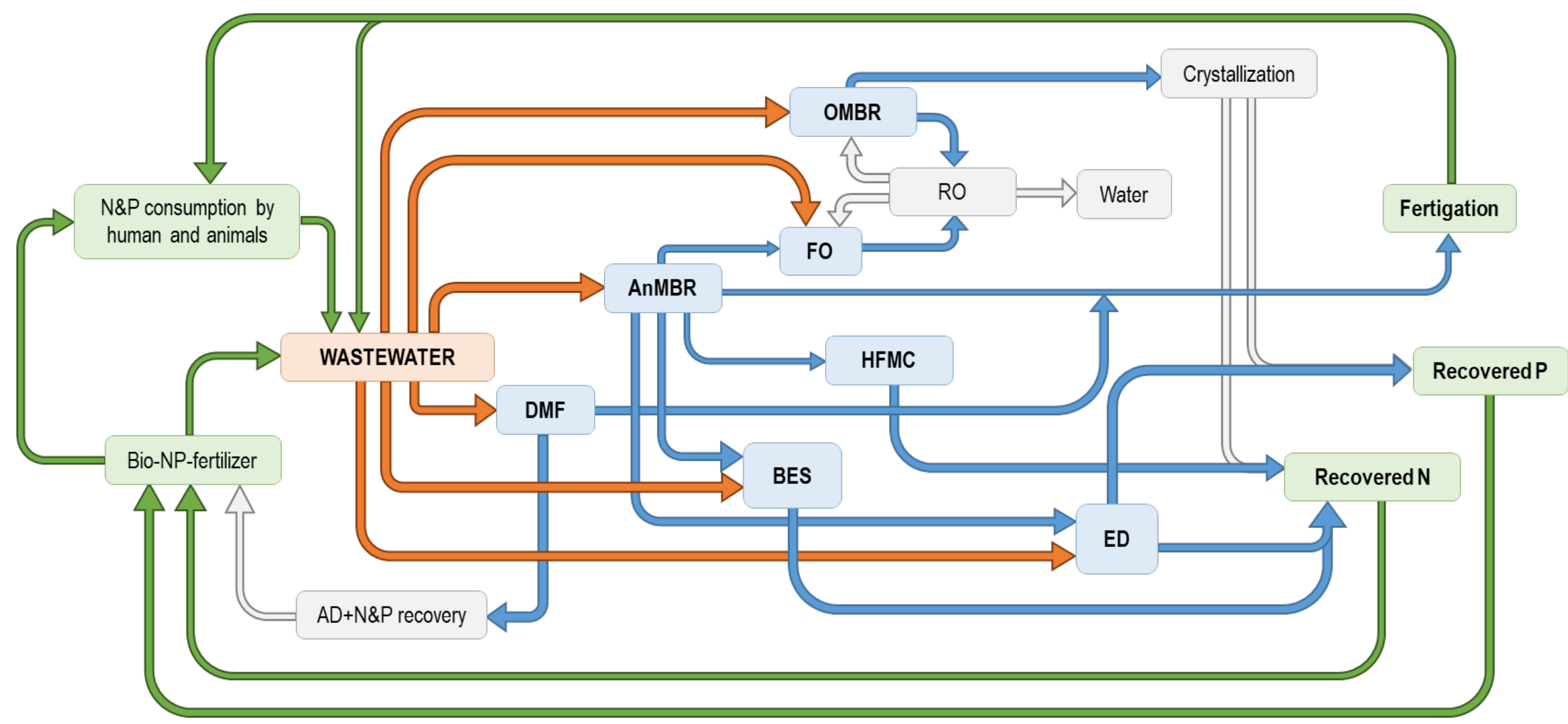

Figure 1. Some possible pathways for nutrient recovery using membranes. Green lines are N and P manufacturing and use. Orange lines are wastewater. Blue lines are membrane-based technologies for $\mathrm{N}$ and $\mathrm{P}$ recovery from wastewater. Grey lines are complementary steps for $\mathrm{N}$ and $\mathrm{P}$ recovery. $\mathrm{AD}$ : anaerobic digestion; AnMBR: anaerobic membrane bioreactor; BES: bioelectrochemical system; DMF: direct membrane filtration: ED: electrodialysis; FO: forward osmosis; HFMC: hollow-fiber membrane contactor; N: nitrogen; OMBR: osmotic membrane bioreactor; P: phosphorus; RO: reverse osmosis. 


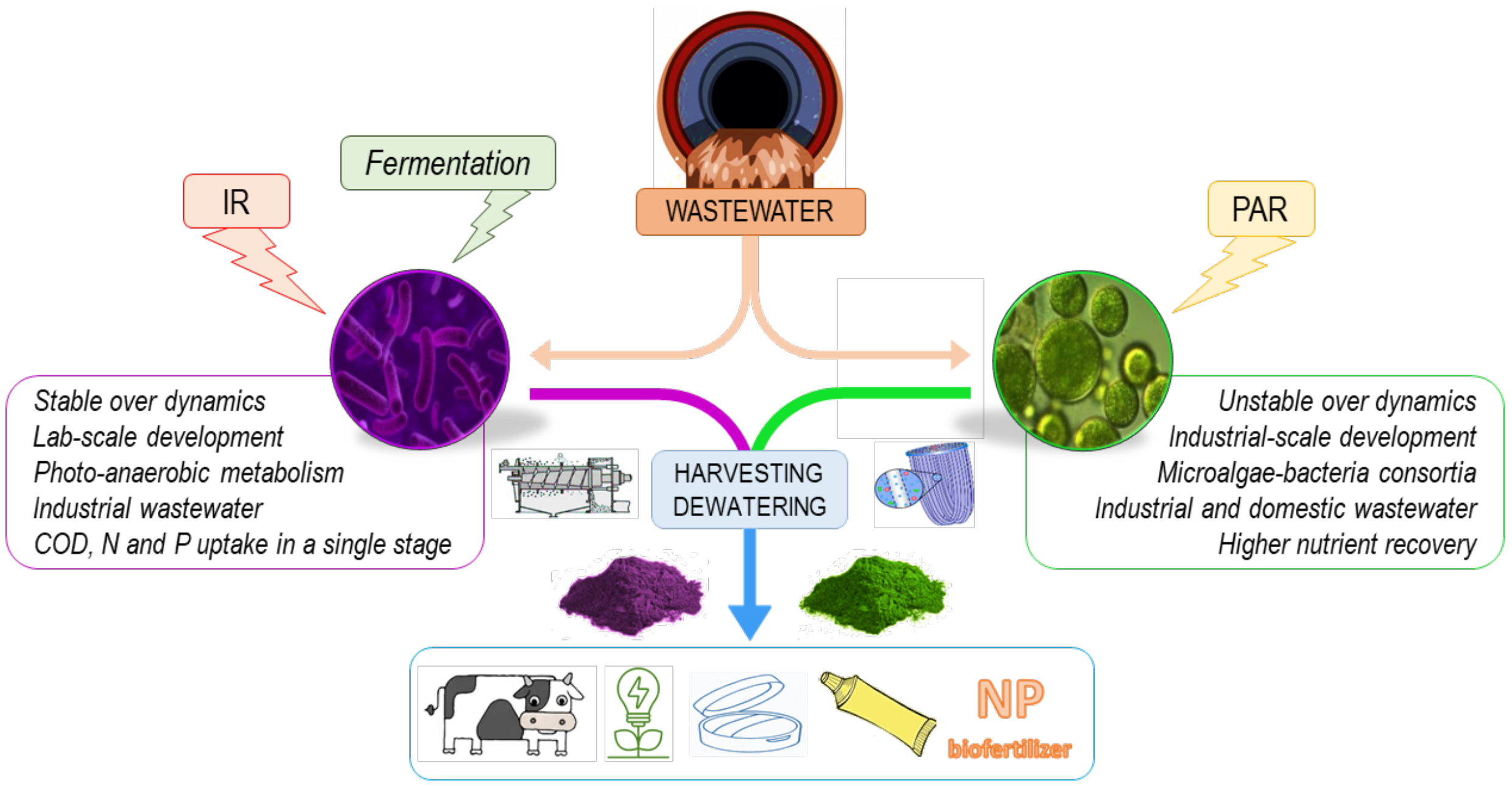

Figure 2. Comparison of microalgae and PSB-based systems for nutrient recovery from wastewater. 


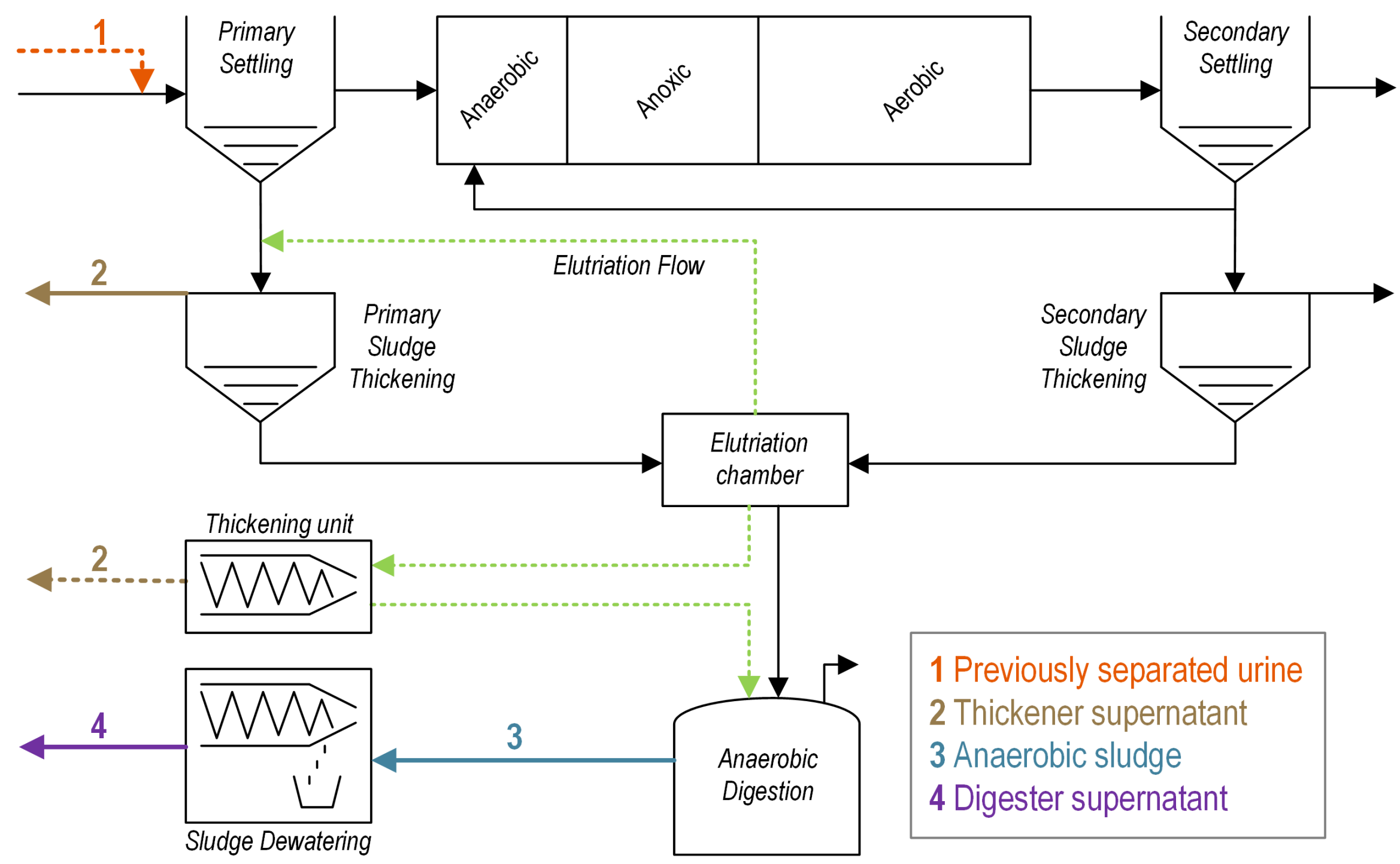

Figure 3. Possible layouts to implement a P-recovery system based on crystallization processes (adapted from Bouzas et al. (2019) and Martí et al. (2017)) 